4 nordon 



\section{Ekonomiska utsikter i Norden 2011}

Nordiska konjunkturgruppens redogörelse hösten 2010 


\section{Ekonomiska utsikter i Norden 2011}

Nordiska konjunkturgruppens redogörelse hösten 2010

TemaNord 2010:601

(c) Nordiska ministerrådet, Köpenhamn 2010

ISBN 978-92-893-2183-9

Publikationen är tillgänglig som Print on Demand (PoD) och kan beställas på www.norden.org/order. Fler publikationer finns på www.norden.org/publikationer.

Nordiska ministerrådet

Ved Stranden 18

DK-1061 Köpenhamn K

Telefon (+45) 33960200

Fax (+45) 33960202

\section{Nordiska rådet}

Ved Stranden 18

DK-1061 Köpenhamn K

Telefon (+45) 33960400

Fax (+45) 33111870

www.norden.org

\section{Det nordiska samarbetet}

Det nordiska samarbetet är ett av världens mest omfattande regionala samarbeten. Det omfattar Danmark, Finland, Island, Norge och Sverige samt de självstyrande områdena Färöarna, Grönland och Åland.

Det nordiska samarbetet är politiskt, ekonomiskt och kulturellt förankrat och är en viktig partner i europeiskt och internationellt samarbete. Den nordiska gemenskapen arbetar för ett starkt Norden i ett starkt Europa.

Det nordiska samarbetet vill styrka nordiska och regionala intressen och värderingar i en global omvärld. Gemensamma värderingar länderna emellan bidrar till att stärka Nordens ställning som en av världens mest innovativa och konkurrenskraftiga regioner. 


\section{Indhold}

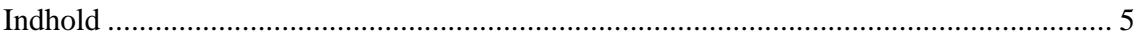

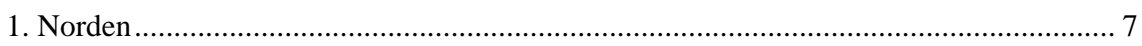

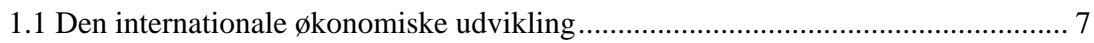

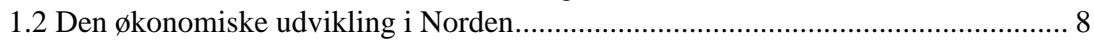

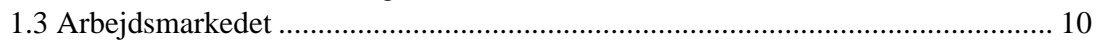

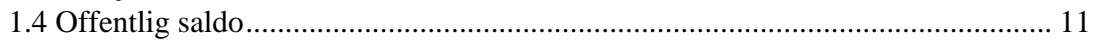

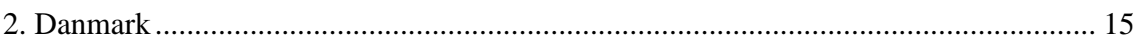

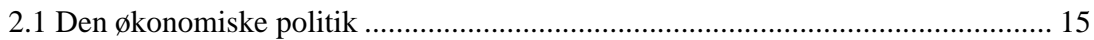

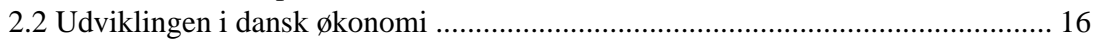

2.3 Udsigterne på mellemlangt sigt ........................................................................ 17

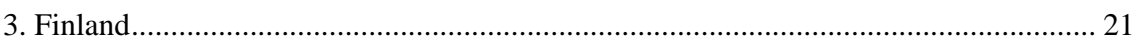

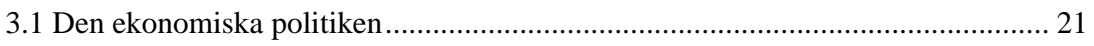

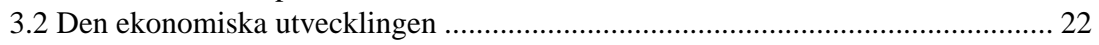

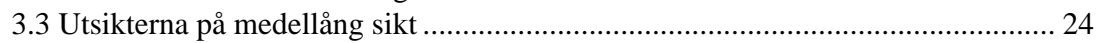

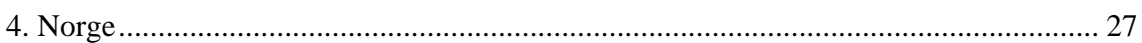

4.1 Den økonomiske politikken.......................................................................... 27

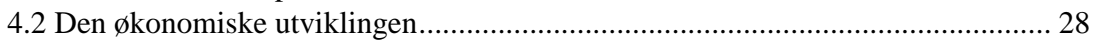

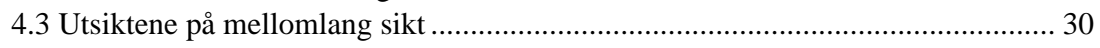

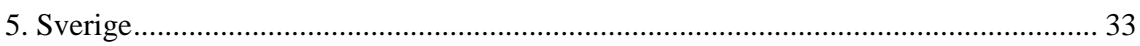

5.1 Recent developments and economic policy ....................................................... 33

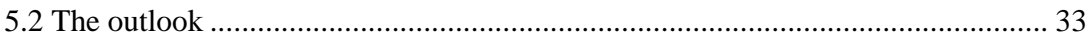

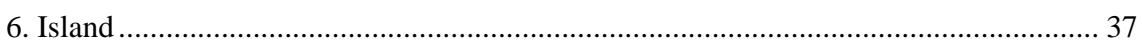

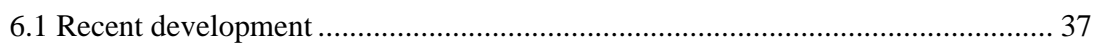

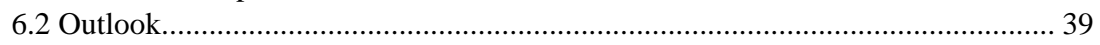

6.3 Fiscal Policy ………………............................................................................. 43 



\section{Norden}

\subsection{Den internationale økonomiske udvikling}

Genopretningen i verdensøkonomien fortsætter. Ifølge IMF forventes aktiviteten i verdensøkonomien at stige med 43/4 pct. i 2010 og med 41/4 pct. i 2011, efter et fald på lidt over $1 \frac{1}{2}$ pct. i 2009. Den forventede vækst i 2010-11 er således højere end gennemsnittet i perioden 2002-08.

Væksttempoet ser imidlertid ud til at have gået lidt ned i gear $\mathrm{i}$ andet halvår i år. Det skal ses i lyset af, at effekterne fra de midlertidige vækstfremmende faktorer som vendingen i lagercyklen og de finanspolitiske lempelser er ved at aftage og endnu ikke fuldt ud er blevet erstattet af mere selvbærende vækstdrivere fra den private efterspørgsel.

Vækstafdæmpningen forventes imidlertid at være midlertidig, og fra første halvår 2011 ventes væksten at tage til igen, blandt andet understøttet af den ekstraordinært lempelige pengepolitik og en bedring i finansmarkederne. På kort sigt forventes væksten i de industrialiserede lande imidlertid ikke at nå op på lige så høje vækstrater som efter tidligere lavkonjunkturer. Det skyldes blandt andet den høje ledighed, en igangværende genopretning af balancer i den private sektor efter formuetab i forbindelse med finanskrisen, samt effekterne fra en samtidig stramning af finanspolitikken i mange lande.

I foråret forværredes forholdene på finansmarkederne markant som følge af svigtende tillid til holdbarheden i de offentlige finanser især i Grækenland, og uroen bredte sig til andre lande, herunder Irland, Portugal og Spanien. Turbulensen medførte faldende aktiekurser og forstærkede allerede eksisterende bekymringer i markedet om holdbarheden af genopretningen.

Til trods for, at forholdene på finansmarkederne er forbedret siden forsommeren, blandt andet som følge af de nye politiske tiltag i euroområdet, er der stadig risici knyttet til genopretningen af de offentlige finanser i mange lande. På det seneste er det Irlands offentlige finanser og især udfordringerne knyttet til den irske banksektor, der har været i fokus.

I de fleste industrialiserede lande er der nu et udtalt behov for finanspolitisk konsolidering. Nogle af de mest udsatte lande har allerede startet konsolideringen, mens mange starter i 2011. Opstramningen er påkrævet både for at skabe en holdbar udvikling i den offentlige gæld og derved sikre tilliden til finanspolitikken, men også for at skabe råderum til at håndtere fremtidige udfordringer.

Der knytter sig stadig en vis usikkerhed til udsigterne, herunder som følge af den uventede vækstafdæmpning, fortsatte svagheder på finansmarkederne, spændinger på valutamarkederne blandt andet som følge af kraftig kapitaltilstrømning til emerging markets og risiko for mere udbredt brug af protektionistiske tiltag. Risikoen for en kraftig global af- 
matning, herunder stagnation eller negativ vækst i industrialiserede økonomier, vurderes imidlertid at være lav.

Udsigterne til et moderat opsving i de industrialiserede lande indebærer, at ledigheden forventes at falde relativt langsomt fra de aktuelt høje niveauer. Der vil således være betydelig ledig kapacitet fremadrettet, og inflationen forventes generelt at forblive lav.

IMF forventer, at væksten i USA gradvist tager til i løbet af 2011-12. Stærk indtjening i virksomhederne og gunstige effekter (til dels laggede) fra en overordnet bedring på finansmarkederne forventes at understøtte investeringerne. Fortsat konsolidering i husholdningerne på baggrund af formuetabet under finanskrisen forventes at indebære en fortsat høj opsparingskvote, men en gradvis forbedring på arbejdsmarkedet forventes at understøtte privatforbruget.

Genopretningen i euroområdet forventes fortsat at være ujævn på tværs af medlemslandene, med højere vækst i "kernelande”, end i "periferien" hvor de finanspolitiske udfordringer er større og i nogle tilfælde er kombineret med et større behov for konsolidering i privat sektor. Samlet forventes den indenlandske efterspørgsel at styrkes gradvist over de næste par år. Efterspørgslen understøttes af den lempelige pengepolitik, stærk indtjening i virksomhederne og en bedring af finansmarkederne. Også her forventes væksten imidlertid at blive dæmpet af den finanspolitiske konsolidering og fortsat tilpasning af balancerne i den private sektor. Forholdene på arbejdsmarkedet forventes langsomt at forbedres og vil, sammen med en moderat nedgang i opsparingskvoten, understøtte privatforbruget.

Væksten forventes fortsat at være høj i de fleste emerging markets og udviklingslande. Det gælder blandt andet i Kina, hvor den indenlandske efterspørgsel forventes at forblive stærk. Mange emerging markets har oplevet et vist inflationspres, blandt andet på baggrund af stigende fødevarepriser og høj kapacitetsudnyttelse, og mange lande har derfor startet normaliseringen af pengepolitikken.

\subsection{Den økonomiske udvikling i Norden}

Der har været vækst igennem første halvår af 2010 i den nordiske region, og prognoserne peger på fortsat fremgang i resten af 2010. Særligt Sverige, men også Finland og Danmark har oplevet kraftig fremgang siden bunden i 2. kvartal 2009. Væksten understøttes af en kraftig genopretning af eksporten og af fremgang i privatbruget. Boligmarkedet er atter i fremgang i flere lande, men investeringerne svækkes blandt andet af fortsat lav kapacitetsudnyttelse. Samlet skønnes en BNP-stigning i 2010 på 2¹/2 pct. ${ }^{1}$, jf. tabel 1 og figur

\footnotetext{
${ }^{1}$ BNP for den nordiske region er beregnet som et vægtet gennemsnit af de enkelte landes BNP. Vægtene er beregnet udfra de enkelte landes relative størrelse målt i BNP i løbende priser, angivet i USD. Datakilde er IMF WEO.
} 
1a. Understøttet af relativt kraftig vækst i investeringerne og i eksporten og privatforbruget skønnes en vækst i BNP på 23/4 pct. i 2011.

Fremgangen i den nordiske region kommer efter, at de nordiske lande har været under kraftig påvirkning af den internationale lavkonjunktur med omfattende produktionsfald til følge. Det stærke fald i verdenshandlen har medført kraftige fald i eksporten og i investeringerne og dermed bidraget stærkt til kraftige fald i produktionen i 2009. Efter omtrent nulvækst i 2008 faldt produktionen i Norden således med 4,8 pct. i 2009.

I Danmark har økonomien været i fremgang siden sommeren 2009. Fremgangen har især været drevet af det kraftige fald i renterne siden efteråret 2008, usædvanligt lempelig finanspolitik og fremgang i eksporten. De offentlige investeringer er planlagt til at stige markant, og det offentlige forbrug er steget mere end planlagt, og bidrager dermed væsentligt til væksten i år. Samtidig understøttes det private forbrug af skattenedsættelser fra årets start og frigivelsen af SP-opsparingen i andet halvår 2009. I den seneste konjunkturvurdering fra december 2010 ventes en stigning i BNP på 2 pct. i 2010. De næste par år ventes væksten gradvist at blive mere selvbærende med fortsat fremgang i privatforbruget og eksporten samt øgede investeringer, mens den offentlige efterspørgsel bidrager negativt til BNP-væksten. Samlet ventes i Økonomiske Redegørelse, december 2010 en vækst i BNP på henholdsvis 13/4 pct. og 1¹/2 pct. i 2011 og 2012.

I Finland er den meget eksportbaserede økonomi igen i fremgang efter et fald i BNP på 8 pct. i 2009, som primært var drevet af kraftige fald i eksporten og i erhvervs- og boliginvesteringer. Der ventes således en vækst i BNP på henholdsvis 2 pct., knap 3 pct. og godt 21/2 pct. i 2010, 2011 og 2012. Eksporten ventes at blive understøttet af den stigende verdenshandel, men eksportvæksten vurderes at ske lidt senere end i andre lande, da investerings- og mellemvareprodukter udgør en relativt stor andel af Finlands eksport. Der ventes således en kraftig vækst i eksporten i 2011 og 2012. De kraftige fald i erhvervs- og boliginvesteringerne i 2009 er i første halvår af 2010 blevet efterfulgt af fortsatte fald i erhvervsinvesteringerne og af stærk vækst i boliginvesteringerne. For 2010 samlet set skønnes et omtrent uændret samlet niveau for investeringerne, hvilket dækker over en stigning i boliginvesteringerne på 15 pct. I 2011 og 2012 skønnes investeringerne at blive understøttet primært af erhvervsinvesteringerne. Finlands høje eksponeringsgrad overfor eksporten samt specialisering i investeringsgoder gør udviklingen i verdenshandlen til en central usikkerhedskilde.

Norge klarede sig bedre igennem krisen end de fleste andre industrilande med et produktionsfald på 1,3 pct. i 2009. Fastlands-Norge har været i vækst siden 4. kvartal 2009, og produktionsniveauet lå i 3. kvartal 2,4 pct. højere end i bunden i samme periode året før. I 3. kvartal steg produktionen i fastlandsøkonomien med 0,9 pct. efter en vækst på 0,5 pct. i de to foregående kvartaler. BNP skønnes i Nasjonalbudsjettet 2011 at stige med 13/4 pct. i 2010 og godt 3 pct. i 2011. Væksten skønnes i høj grad at afspejle fremgang i 
privatforbruget og vækst i eksporten som følge af en stærk udvikling hos vigtige samhandelslande såsom Tyskland og Sverige.

Sverige har oplevet en stærk genopretning efter den internationale økonomiske krise, og fremgangen ventes at fortsætte. Understøttet af særligt eksporten, privatforbruget og investeringerne har der været en fremgang i BNP på 4,8 pct. i forhold til bunden i 1. kvartal 2009. Der skønnes en vækst på 4,8 pct., 3,7 pct. og 3,4 pct. i henholdsvis 2010, 2011 og 2012. På trods af den stærke vækst i 2010 er kapacitetsudnyttelsen fortsat lav, og investeringerne skønnes at stige i takt med en stigende udnyttelse af produktionskapaciteten. Den disponible indkomst er understøttet af den ekspansive pengepolitik og af finanspolitiske tiltag. Privatforbruget ventes desuden øget i kraft af et fald i opsparingskvoten fra et historisk højt niveau.

Efter en historisk kraftig krise brød ud mod slutningen af 2008, faldt BNP i Island med 6,8 pct. i 2009. Mod slutningen af 2009 var der tegn på en stabilisering af økonomien, men indikatorer peger på yderligere fald i BNP i første halvdel af 2010 som følge af en svagere udvikling i privatforbruget og eksporten samt de negative økonomiske effekter af vulkanudbruddet i marts/april. Understøttet af privatforbruget og investeringerne ventes atter vækst i andet halvår af 2010, og samlet ventes BNP at falde med 3 pct. i 2010. Stærk vækst i investeringerne især i 2011 ventes at bidrage til en vækst på henholdsvis 3 pct. og 2¹/2 pct. i 2011 og 2012.

\subsection{Arbejdsmarkedet}

Beskæftigelsen i de nordiske lande har været faldende under den økonomiske afmatning siden 2007-2008, men stærkt understøttet af den meget lempelige økonomiske politik ser beskæftigelsen ud til at have nået en bund. I den nordiske region samlet set er ledigheden steget til 6,3 pct. i 2009 fra 4,6 pct. i 2008, jf. tabel 1 og figur $1 b^{2}$. Ledigheden vurderes at nå et toppunkt i 2010 med godt 61/2 pct. for derefter at aftage en smule til 61/2 pct. i 2011.

Udviklingen i beskæftigelse og ledighed Danmark i den forløbne del af 2010 peger på, at arbejdsmarkedet er nogenlunde stabiliseret efter et markant fald i beskæftigelsen på ca. 160.000 personer (51/2 pct.) siden "toppen” i 4. kvartal 2008, hvor kapacitetsudnyttelsen dog var usædvanligt høj. Nedgangen i beskæftigelsen er sket i den private sektor, hvor beskæftigelsesfaldet har været på godt 180.000 personer. Ledigheden er øget, men dog væsentligt mindre end ventet. Selv om langtidsledigheden er steget i et højt tempo som følge af nedgangen i konjunkturerne, så er niveauet fortsat forholdsvis lavt i historisk og international sammenhæng. I Økonomisk Redegørelse, december 2010 skønnes den registrerede le-

\footnotetext{
${ }^{2}$ Ledigheden for den nordiske region er beregnet som et vægtet gennemsnit af de enkelte landes ledighed som andel af arbejdsstyrken. Vægtene er beregnet udfra befolkningsstørrelse. Som datakilde er anvendt IMF WEO. Kilden til de enkelte landes ledighedsandel er de officielle nationale institutioner, og der kan således være anvendt forskellige ledighedsdefinitioner.
} 
dighed at toppe med godt 41/4 pct. omkring 1. kvartal 2011 og på årsbasis at udgøre henholdsvis 4 pct. i 2010 og henholdsvis 41/4 pct. og 4 pct. i 2011 og 2012. Bruttoledigheden, som også indeholder antallet af arbejdsmarkedsparate aktiverede, ventes at udgøre henholdsvis 53/4 pct., 6 pct. og 53/4 pct. af arbejdsstyrken i 2010-2012.

Faldet i beskæftigelsen i Finland siden 2008 er ved at tage af, og den ventes at nå en bund i 2010. Med en skønnet ledighed på godt $81 \frac{1}{2}$ pct. af arbejdsstyrken i 2010 mod 61/2 pct. i 2008, er ledigheden forholdsvis høj. Økonomisk vækst og finanspolitiske tiltag skønnes at styrke arbejdsmarkedet i 2011 gennem flere jobs indenfor industri og service, og ledigheden skønnes at falde til 81/4 pct. i 2011. Arbejdsudbuddet svækkes fremadrettet af, at populationen af 15-64-årige vurderes at falde med 20.000 personer ( $3 / 4$ pct.) årligt.

Beskæftigelsen i Norge faldt fra 3. kvartal 2008 indtil 3. kvartal 2009, og efter en stabil udvikling frem til 1. kvartal 2010 steg beskæftigelsen i 2. kvartal og 3. kvartal. Ledigheden er steget svagt fra 3,2 pct. i 2009 til omkring 31/2 pct. i første halvår af 2010, hvilket fortsat er lavere end det gennemsnitlige niveau for de seneste 20 år. I Nasjonalbudsjettet 2011 skønnes en mindre stigning i beskæftigelsen igennem resten af 2010 og i 2011, mens ledigheden er skønnet til henholdsvis 31/2 pct. og godt 31/2 pct. i 2010 og 2011.

Den kraftige økonomiske vækst og tiltagende optimisme i erhvervslivet i Sverige bidrager til stigende beskæftigelse. Ledigheden toppede i starten af 2. kvartal på 9 pct. af arbejdsstyrken og er efterfølgende faldet til omkring 8,2 pct. i 3. kvartal. For hele året skønnes en ledighed på 8,4 pct., hvilket er omtrent uændret i forhold til 2009. Beskæftigelsen skønnes at stige med 220.000 personer i perioden 2010-2014 som følge af den økonomiske vækst, politiske tiltag og en stigning i den arbejdsdygtige aldersgruppe. Ledigheden ventes at falde fra knap 81ำ pct. i 2010 til 6 pct. i 2014.

Det kraftige fald i beskæftigelsen i Island siden krisens begyndelse nåede en ende i 1. kvartal 2010, og beskæftigelsen er steget igennem 2. og 3. kvartal. I 1. kvartal var ledigheden steget til 9,3 pct., men er efterfølgende faldet til omkring 7 pct. For hele 2010 skønnes ledigheden at stige til 83/4 pct. mod 71/2 pct. i 2009. I 2011 skønnes ledigheden at falde en anelse til knap $8 \frac{1}{2} 2$ pct.

\subsection{Offentlig saldo}

Stærke automatiske stabilisatorer og lempelig finanspolitik har bidraget til, at de offentlige finanser i Norden er blevet kraftigt svækket i forbindelse med den internationale krise. De store saldooverskud i Sverige, Finland og Danmark i 2007 og 2008 er vendt til betydelige underskud i 2009, og der ventes fortsatte underskud i 2010 og 2011. Norges solide offentlige finanser er ligeledes svækket kraftigt i samme periode, men udviser fortsat store overskud. Island har haft markante underskud både i 
2008 og i 2009, som ventes nedbragt markant fremover i medfør af implementeringen af IMF's genopretningsprogram. For den nordiske region samlet set er saldooverskuddet faldet fra 6,0 pct. af BNP i 2008 til 0,2 pct. af BNP i 2009 - et samlet overskud som udelukkende skyldes Norges kraftige overskud, jf. tabel 1 og figur $2 a^{3}$. Finanspolitisk konsolidering bidrager til at vende de offentlige finanser fra et underskud på knap $1 / 2$ pct. af BNP i 2010 til et overskud på knap 1⁄2 pct. af BNP i 2011.

De offentlige finanser i Danmark er blevet kraftigt svækket af krisen og den lempelige finanspolitik, og det offentlige underskud ventes at udgøre godt 31/2 pct. af BNP i 2010, knap 43/4 pct. af BNP i 2011 og knap $3 \frac{1}{2}$ pct. i 2012. Forværringen af de offentlige finanser har medført, at Danmark er inde i Stabilitets- og Vækstpagtens "procedure for uforholdsmæssigt store underskud" og som følge heraf modtog Danmark i juli 2010 en henstilling fra Rådet af EU’s økonomi- og finansministre (ECOFIN) om at styrke de offentlige finanser. Henstillingen indebærer, at den strukturelle offentlige saldo skal forbedres med $1 \frac{1 / 2}{2 c t}$. af BNP i løbet af 2011 til 2013 svarende til nye initiativer for i alt 24 mia. kr. Genopretningsaftalen fra foråret indfrier denne henstilling.

Det kraftige produktionsfald i 2009 og den finanspolitiske stimulans førte i 2009 til det første saldounderskud i Finland siden 1997. Stærke automatiske stabilisatorer bidrog til, at saldoen i 2009 blev svækket med 7 pct.-enheder i forhold til 2008. En forventet lav vækst og en fortsat svækkelse af arbejdsmarkedet samt yderligere finanspolitiske lempelser betyder, at underskuddet skønnes at stige fra 23/4 af BNP i 2009 til 3¹/4 pct. af BNP i 2010, men så falde til 11/2 pct. i 2011. Den offentlige gæld vurderes at stige med 18 pct.-enheder af BNP i perioden 2008-2012.

I Norge bidrog en væsentlig finanspolitisk stimulans til, at overskuddet på den offentlige saldo faldt fra godt 19 pct. af BNP i 2008 til godt 10 pct. af BNP i 2009. Med baggrund i udsigten til en vækst over trendniveauet i 2011 og fortsat lav ledighed er der i Statsbudsjettet for 2011 lagt op til en opstramning af den strukturelle saldo for staten efter fortsat finanspolitisk stimulans i 2010. Samlet skønnes i 2010 og 2011 et overskud på den offentlige saldo på 91/2-93/4 pct. af BNP.

I Sverige ventes et underskud på den offentlige saldo på 1,3 pct. af BNP i 2010, hvilket omtrent svarer til underskudet året før. I 2011 ventes underskuddet at udgøre 0,4 pct. af BNP.

Den meget kraftige økonomiske og finansielle krise i Island medførte en markant svækkelse af de offentlige finanser og et saldounderskud på 13,5 pct. af BNP i 2008 og 9,1 pct. af BNP i 2009. Implementeringen af IMF's Stand-By-Arrangement (SBA) program har bidraget til at bringe de offentlige finanser tilbage på sporet, og der skønnes en kraftig forbedring af saldoen til $-6 \frac{1}{2}$ pct. i 2010 og $-23 / 4$ pct. i 2011. Begrænsninger af

\footnotetext{
${ }^{3}$ Beregnet som et vægtet gennemsnit af de enkelte landes offentlige saldo. Vægtene er beregnet udfra de enkelte landes relative størrelse målt i BNP i løbende priser, angivet i USD. Datakilde er IMF WEO.
} 
det offentlige forbrug tegner sig for godt halvdelen af konsolideringstiltagene. Regeringens mål er at opnå overskud på den strukturelle saldo i 2011 og overskud på den faktiske saldo i 2013.

Tabel 1

\begin{tabular}{|c|c|c|c|c|c|c|}
\hline \multicolumn{7}{|l|}{ Nøgletal, Nordiske lande } \\
\hline & 2007 & 2008 & 2009 & 2010 & 2011 & 2012 \\
\hline BNP & \multicolumn{6}{|c|}{ Årlig vækst i pct. } \\
\hline Danmark & 1,6 & $-1,1$ & $-5,2$ & 2,0 & 1,7 & 1,5 \\
\hline Finland & 5,3 & 0,9 & $-8,0$ & 2,1 & 2,9 & 2,6 \\
\hline Norge & 5,6 & 1,8 & $-1,3$ & 1,7 & 3,1 & \\
\hline Sverige & 3,3 & $-0,4$ & $-5,1$ & 4,8 & 3,7 & 3,4 \\
\hline Island & 6,0 & 1,0 & $-6,8$ & $-3,0$ & 1,9 & \\
\hline Norden $^{1}$ & 3,3 & 0,0 & $-4,8$ & 2,6 & 2,8 & \\
\hline Inflation & \multicolumn{6}{|c|}{ Årlig vækst i pct. } \\
\hline Danmark & 1,7 & 3,4 & 1,3 & 2,3 & 1,7 & 1,7 \\
\hline Finland & 2,5 & 4,1 & 0,0 & 1,5 & 2,5 & 2,0 \\
\hline Norge & 0,8 & 3,8 & 2,1 & 2,5 & 1,8 & \\
\hline Sverige & 2,2 & 3,4 & $-0,3$ & 1,2 & 1,5 & 1,9 \\
\hline Island & 5,0 & 12,4 & 12,0 & 5,4 & 2,3 & 2,5 \\
\hline Norden $^{2}$ & 2,2 & 3,4 & $-0,3$ & 1,2 & 1,5 & \\
\hline Ledighed (nat. definitioner) & \multicolumn{6}{|c|}{ Pct. af arbejdsstyrke } \\
\hline Danmark & 2,7 & 1,7 & 3,4 & 4,0 & 4,2 & 4,0 \\
\hline Finland & 6,9 & 6,4 & 8,2 & 8,6 & 8,2 & 7,9 \\
\hline Norge & 2,5 & 2,5 & 3,2 & 3,5 & 3,6 & \\
\hline Sverige & 6,1 & 6,2 & 8,3 & 8,4 & 8,0 & 7,4 \\
\hline Island & 1,0 & 1,6 & 8,0 & 8,2 & 7,3 & 5,6 \\
\hline Norden $^{2}$ & 4,9 & 4,6 & 6,3 & 6,6 & 6,5 & \\
\hline Offentlig saldo & \multicolumn{6}{|l|}{ Pct. af BNP } \\
\hline Danmark & 4,8 & 3,3 & $-2,8$ & $-3,6$ & $-4,7$ & $-3,4$ \\
\hline Finland & 5,2 & 4,2 & $-2,7$ & $-3,3$ & $-1,4$ & $-0,8$ \\
\hline Norge & 17,7 & 19,3 & 10,3 & 9,7 & 9,6 & \\
\hline Sverige & 3,5 & 2,2 & $-1,2$ & $-1,3$ & $-0,4$ & 1,0 \\
\hline Island & 5,4 & $-11,8$ & $-8,7$ & $-6,4$ & $-3,3$ & \\
\hline Norden $^{1}$ & 7,0 & 6,0 & 0,2 & $-0,2$ & 0,4 & \\
\hline Betalingsbalance & \multicolumn{6}{|l|}{ Pct. af BNP } \\
\hline Danmark & 1,4 & 2,7 & 3,6 & 4,5 & 3,9 & 3,8 \\
\hline Finland & 4,2 & 3,5 & 1,3 & 1,4 & 1,1 & 0,7 \\
\hline Norge & 14,1 & 17,8 & 13,1 & 16,3 & 15,3 & \\
\hline Sverige & 8,5 & 8,8 & 7,5 & 6,7 & 7,2 & 7,1 \\
\hline Island & $-16,0$ & $-22,0$ & $-3,8$ & 0,5 & $-0,9$ & \\
\hline Norden $^{1}$ & 6,9 & 7,7 & 6,4 & 7,0 & 6,7 & \\
\hline
\end{tabular}

Kilder: Nationale kilder og IMF

1) Beregnet som et vægtet gennemsnit af de enkelte lande. Vægtene er beregnet udfra de enkelte landes relative størrelse målt i BNP i løbende priser, angivet i USD. Datakilde er IMF WEO.

2) Ledigheden for den nordiske region er beregnet som et vægtet gennemsnit af de enkelte landes ledighed som andel af arbejdsstyrken. Vægtene er beregnet udfra befolkningsstørrelse. Som datakilde er anvendt IMF WEO. Kilden til de enkelte landes ledighedsandel er de officielle nationale institutioner, og der kan således være anvendt forskellige ledighedsdefinitioner. 
Figur 1a - BNP vækst, Norden

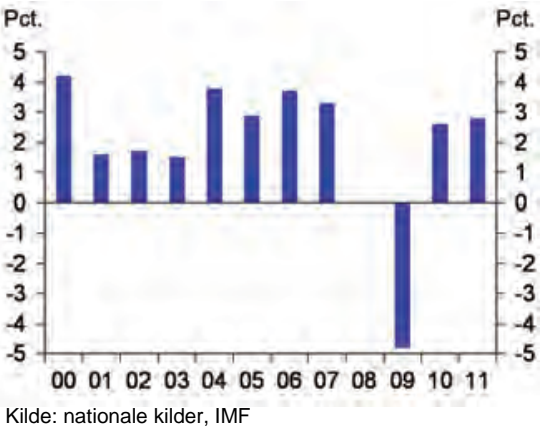

Figur 2a - Offentlig saldo

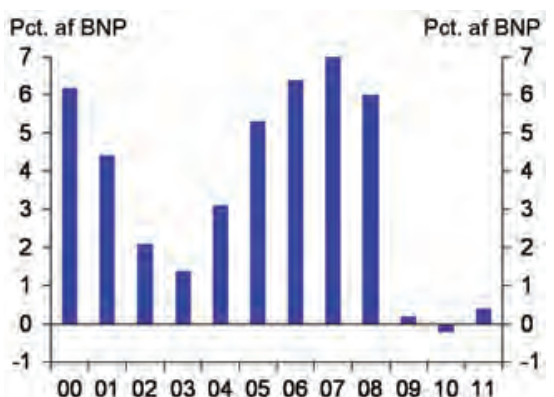

kilde: nationale kilder, IMF
Figur $1 \mathrm{~b}$ - Ledighed, Norden

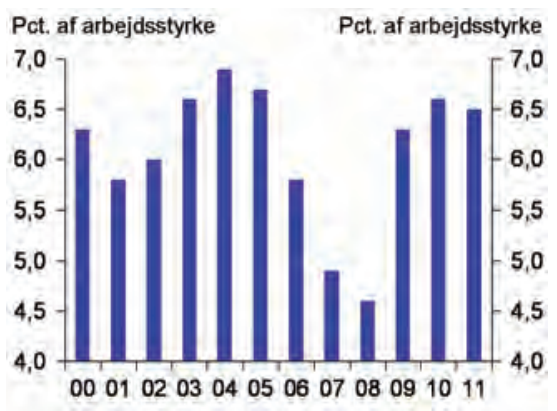

Figur 2b-Betalingsbalance

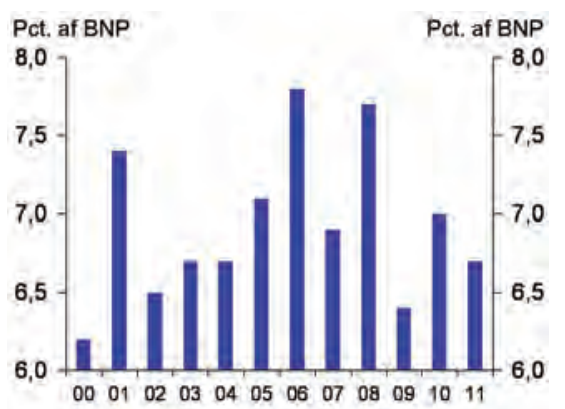




\section{Danmark}

\subsection{Den økonomiske politik}

Fremgangen i den danske økonomi efter krisen er blevet understøttet af markante penge- og finanspolitiske lempelser i 2009 og 2010, som også virker ind i 2011. Den lempelige finanspolitik har været med til at vende udviklingen, men har samtidig bidraget til forværringen af de offentlige finanser, som samlet udgør knap 7 pct. af BNP fra 2008 til 2010. I 2010 ventes underskuddet at udgøre 3,6 pct. af BNP, hvilket er et stykke over grænsen i Stabilitets- og Vækstpagten på 3 pct. af BNP. Danmark er på den baggrund kommet ind under i Stabilitets- og Vækstpagtens "procedure for uforholdsmæssigt store underskud" (EDP). Danmark modtog som følge heraf i midten af juli en henstilling fra Rådet af EU’s økonomi- og finansministre (ECOFIN) om at styrke de offentlige finanser. Henstillingen indebærer, at den strukturelle offentlige saldo skal forbedres med i alt 11/2 pct. af BNP i løbet af 2011 til 2013 svarende til nye initiativer for i alt 24 mia. kr. Henstillingen til Danmark er mildere end for stort set alle andre EU-lande i proceduren. Det afspejler et bedre udgangspunkt for de offentlige finanser, da krisen eskalerede, end i andre lande, fordi der blev sparet op og afdraget på gælden under højkonjunkturen.

Rettidig konsolidering vil styrke troværdigheden omkring den økonomiske politik, herunder fastkurspolitikken. Det er afgørende i en tid, hvor mange landes statsgældsproblemer har medført uro og usikkerhed på de finansielle markeder.

Desuden vil konsolidering sikre lave renter, som understøtter efterspørgslen, fordi Danmark er en relativt rentefølsom økonomi. Det skyldes, at husholdningerne har en stor finansiel nettogæld med variabel forrentning, og at boligefterspørgslen er meget rentefølsom. Faldet i renterne siden slutningen af 2008 har stor betydning for vendingen i økonomien men modstykket er, at dansk økonomi er følsom, når renten stiger igen.

Danmark påbegynder konsolideringen i 2011 i overensstemmelse med EU's henstilling. Med genopretningsaftalen fra maj 2010 er der truffet konkrete beslutninger om konsolidering af den offentlige økonomi i årene 2011 til 2013, som indfrier EU-henstillingen. Genopretningsaftalen indebærer en vis forøgelse af beskatningen, mindre udgiftsvækst end planlagt hidtil og strukturreformer på arbejdsmarkedet, som øger arbejdsudbuddet på længere sigt.

Finanspolitikken i årene 2009-2011 skønnes samlet set og med nogen usikkerhed at være omtrent neutral for efterspørgselsvæksten i 2011 (målt ved den flerårige finanseffekt), selv om den planlagte finanspolitik i 2011 isoleret set har en aktivitetsvirkning, som skønnes til -0,3 pct. af BNP. 
Det skal ses i lyset af, at lempelserne i 2009 og især i 2010 også har forsinkede positive virkninger på efterspørgslen i 2011. Tallene indregner ikke tiltagene til sikring af finansiel stabilitet, som samlet har forhindret et dybere tilbageslag i dansk økonomi.

Udover de forsinkede virkninger fra lempelserne i 2009 og 2010 skal finanspolitikken i 2011 også ses i sammenhæng med den meget lempelige pengepolitik og de lave lange renter i Danmark. Samlet peger modelberegninger på, at faldet i renteniveauet fra og med 2009 medfører en aktivitetsvækst i 2011 svarende til 11/2 pct. af BNP.

Det samlede aktivitetsbidrag fra finanspolitikken og rentevirkninger mv. skønnes til 11/4 pct. i 2011. Heri er indregnet, at de forudsatte aktivitetsvirkninger fra udbetalingen af SP dæmpes i 2011.

Virkningen af finanspolitikken i 2012 svarer til bidraget fra den étårige finanseffekt, som i 2012 skønnes til -0,5 pct. af BNP. Finanseffekten afspejler fald i de offentlige investeringer, en forholdsvis beskeden vækst i det offentlige forbrug samt indtægtsstramninger i genopretningsaftalen. Det er således først i 2012, at konsolideringen slår fuldt igennem i aktivitetsvirkninger.

\subsection{Udviklingen i dansk økonomi}

Dansk økonomi er igen i vækst. Det store fald i produktion og efterspørgsel, der fulgte i kølvandet på finanskrisen, er vendt til pæn fremgang siden sommeren 2009. Foreløbige oplysninger om beskæftigelsesudviklingen i den forløbne del af 2010 peger på, at arbejdsmarkedet er nogenlunde stabiliseret, og stigningen i bruttoledigheden (registrerede ledige og aktiverede) har været mere afdæmpet end ventet. Der er fortsat usikkerhed om væksten de næste år blandt andet som følge af den internationale statsgældskrise, men væksten understøttes blandt andet af lave renter og begyndende fremgang på boligmarkedet, ret høj realindkomstfremgang, og at den internationale økonomi er inde i et moderat opsving. Desuden er de finansielle markeder gradvist ved at løsne op.

I den seneste konjunkturvurdering fra december 2010 ventes det, at BNP vil stige med 2,0 pct. i 2010, 1,7 pct. i 2011 og 1,5 pct. i 2012. Fremgangen har især været drevet af det kraftige fald i renterne siden efteråret 2008 og usædvanligt lempelig finanspolitik. De offentlige investeringer er planlagt til at stige markant, og det offentlige forbrug er steget mere end planlagt og bidrager dermed væsentligt til væksten i år. Samtidig understøttes det private forbrug af skattenedsættelser fra årets start og frigivelsen af SP-opsparingen i andet halvår 2009. De næste par år ventes væksten gradvist at blive mere selvbærende med fortsat fremgang i privatforbruget og stigende eksport og investeringer.

Beskceftigelsen er faldet markant med ca. 160.000 personer (51/2 pct.) siden "toppen” i 4. kvartal 2008. Faldet i beskæftigelsen er sket i den 
private sektor, hvor nedgangen har været på godt 180.000 personer. Samlet er beskæftigelsesniveauet imidlertid fortsat lidt større end i 2005, der betragtes som et forholdsvist normalt konjunkturår. Det skal ses i lyset af, at den strukturelle beskæftigelse skønsmæssigt er steget med omkring 100.000 personer siden 2005 blandt andet som følge af, at den strukturelle ledighed er reduceret.

Selv om langtidsledigheden er steget i et højt tempo som følge af nedgangen i konjunkturerne, så er niveauet fortsat forholdsvis lavt i historisk og international sammenhæng. Det samme gælder ungdomsarbejdsløsheden. Det skal blandt andet ses i sammenhæng med, at langtidsledigheden var ekstraordinært lav, da krisen eskalerede. Samtidig har de fleksible regler for afskedigelser og ansættelser og den aktive arbejdsmarkedspolitik bidraget til høj jobomsætning, og til at ledige kan finde beskæftigelse.

Krisen og den lempelige finanspolitik har svækket de offentlige finanser, og det offentlige underskud ventes at udgøre godt $3 \frac{1}{2}$ pct. af BNP i 2010. I 2011 og 2012 ventes underskud på henholdsvis 43/4 pct. og knap 31/2 pct. af BNP. Det strukturelle underskud forventes øget til knap 2 pct. af BNP i 2010 som følge af lempelserne. I 2011 og 2012 styrkes den strukturelle saldo, og underskuddet ventes at udgøre henholdsvis omkring $1 \frac{1 / 4}{4}$ pct. og $3 / 4$ pct. af BNP. To tredjedele af kravet om en forbedring af den strukturelle saldo med 11/2 pct. af BNP fra 2010 til 2013 indfries således i løbet af 2011 og 2012. I fravær af nye konsolideringstiltag ventes det strukturelle underskud at stige de næste årtier. Der er derfor nødvendigt at stramme finanspolitikken.

\subsection{Udsigterne på mellemlangt sigt}

Finanspolitikken tilrettelægges efter den flerårige økonomiske plan Mod nye mål - Danmark 2015. 2015-planen sigter blandt andet på at sikre finanspolitisk holdbarhed, således at velfærdssamfundet også kan finansieres på langt sigt, uden at der fremkommer et behov for større fremtidige finanspolitiske stramninger.

De centrale omdrejningspunkter for finanspolitikken i 2015-planen er at sikre strukturel balance på de offentlige finanser i 2015 og langsigtet finanspolitisk holdbarhed, jf. Danmark 2015 - Mod Nye Mål, august 2007. 2015-planen er senest blevet opdateret i Konvergensprogram 2009, hvor de centrale finanspolitiske mål, som konsolideringsforløbet er bygget op om, er:

- Fastholdelse af den centrale målsætning i 2015-planen om strukturel balance i 2015 (Danmarks Medium Term Objective). Det indebærer at finanspolitikken opfylder kravet om holdbarhed.

- Efterlevelse af EU-henstillingen om en forbedring af den strukturelle offentlige saldo med i alt 1¹/2 pct. af BNP i perioden 2011 til 2013. 
I Konvergensprogrammet er den konsolidering, som kræves for at efterleve EU-henstillingen opgjort til nye initiativer for $24 \mathrm{mia}$. kr.

Med genopretningsaftalen forbedres den strukturelle saldo samlet med 11/2 pct. af BNP i perioden 2011-2013. Aftalen forbedrer derudover finanserne med yderligere godt 2 mia. kr. frem mod 2015, navnlig som følge af beskæftigelsesvirkningerne af dagpengereformen. Dermed udestår initiativer for ca. 5 mia. kr. for at indfri målsætningen om strukturel balance på de offentlige finanser i 2015.

Af den samlede forbedring af de offentlige finanser i genopretningsaftalen kan ca. 101/2 mia. kr. henføres til mindreudgifter til offentligt forbrug i forhold til den tidligere planlagte udgiftsvækst. Aftalen medvirker til, at det offentlige forbrug henholdsvis falder og stiger med 0,3 pct.point i 2011 og 2012 samt falder lidt i 2013.

Det er en central udfordring at sikre, at udgifterne følger det planlagte spor i 2011-2013, og det er et vigtigt element i genopretningsaftalen. Derfor er der truffet beslutning om skærpede styringsmekanismer for det offentlige forbrug.

Udover lavere vækst i det offentlige forbrug indebærer genopretningsaftalen, at den planlagte forhøjelse af topskattegrænsen udskydes, at der indføres loft over fradrag for fagforeningskontingent mv., samt at de automatiske reguleringer af beløbsgrænser i skattesystemet suspenderes i perioden 2011-2013. Samlet set bidrager skatteelementerne i genopretningsaftalen til, at den offentlige saldo forbedres med 5 mia. kr. i 2011 og godt 10 mia. kr. i 2013 i forhold til forløbet i Konvergensprogram 2009. Heraf er ca. 2 mia. kr. udtryk for at en planlagt reduktion af beskatningen udskydes til 2014 (før tilbageløb mv.).

Endeligt indebærer genopretningsaftalen, at den maksimale dagpengeperiode halveres fra 4 til 2 år, og reglerne for optjening og genoptjening af dagpengeretten harmoniseres, så der nu i alle tilfælde kræves 52 ugers fuldtidsbeskæftigelse indenfor de seneste 3 år (mod før 26 uger). Dermed forbedres strukturerne på arbejdsmarkedet permanent, og det anslås, at reformen sammen med de øvrige tiltag i genopretningsaftalen medfører en stigning i den strukturelle beskæftigelse på lidt længere sigt svarende til omkring 10.000 personer. Reformen af dagpengesystemet ventes isoleret set at styrke den offentlige saldo med 13/4 mia. kr. i 2013 ekskl. virkningerne på arbejdsudbuddet. Fra 2015 og frem, hvor beskæftigelsesvirkningerne er indregnet, styrkes saldoen permanent med 41/2 mia. kr. som følge af reformen.

Det fremgår af regeringens arbejdsprogram og af genopretningsaftalen, at regeringen vil tage de nødvendige initiativer for at øge det samlede arbejdsudbud frem mod 2020. Blandt andet ventes forslag vedrørende førtidspension og hurtigere studiegennemførelse at bidrage til at indfri de resterende 5 mia. kr.

Den planlagte konsolidering og de yderligere forudsatte forbedringer for 5 mia. kr. frem mod 2015 styrker de offentlige finanser på lang sigt. 
Efter 2019 styrkes saldoen desuden af tilbagetrækningsreformerne, som blev vedtaget i forbindelse med Velfærdsaftalen fra 2006, og som indebærer, at efterløns- og pensionsalderen forøges med 2 år og derefter indekseres med udviklingen i levetiden.

På trods af dette er der ved uændret finanspolitik udsigt til en markant forværring af den strukturelle saldo efter 2015, og det strukturelle underskud kan i en periode blive større end 3 pct. af BNP. Finanserne forbedres i forløbet efter omkring 2040, efterhånden som Velfærdsaftalen har fuld virkning på den mulige periode med efterløn og pension, og fordi det demografiske pres på finanserne aftager. Forløbet indebærer som nævnt, at gælden stabiliseres på langt sigt, og at finanspolitikken er holdbar.

Det internationale økonomiske tilbageslag har i Danmark - som i andre OECD-lande - medført en nedjustering af produktionspotentialet. Samlet er det i den seneste prognose fra december 2010 lagt til grund, at den potentielle vækst er 11/4 pct. årligt i perioden 2010-2012.

Væksten i produktionspotentialet for dansk økonomi er for perioden 2013-15 anslået til 1,4 pct. i gennemsnit pr. år, jf. Konvergensprogram 2009. Det afspejler, at det underliggende fald i den strukturelle beskæftigelse i timer som følge af demografi og lavere indvandring omtrent modsvares af reformer. For perioden 2015-2020 forudsættes potentiel BNP tilsvarende at vokse med knap 1 1/2 pct. årligt. Det er antaget, at timeproduktiviteten underliggende vokser med 11/2 pct. om året.

Væksten i produktionspotentialet frem mod 2020 er lavere end i perioden 1991-2006. Det afspejler navnlig, at faldet i den strukturelle ledighed på godt 5 pct.-enheder fra starten af 1990'erne ikke kan gentages. Strukturledigheden er på et historisk lavt niveau og anslås at udgøre 3,7 pct. af arbejdsstyrken i 2009.

Yderligere vækst i produktionspotentialet udover 11/2 pct. vil kræve reformer, som kan øge beskæftigelsen, og navnlig øget vækst i produktiviteten. Der er de seneste år gennemført betydelige reformer af skatte- og arbejdsmarkedspolitikken, og fremtidigt reformpotentiale skal ses i lyset heraf.

I internationale sammenligninger fremstår de underliggende strukturer og rammebetingelser i dansk økonomi grundlæggende gode. Ledigheden og langtidsledigheden er forholdsvis lav, beskæftigelsen er ret høj og rammebetingelserne for vækst anses normalt for at være gode, jf. OECD Economic Survey of Denmark 2009.

Produktivitetsvæksten i Danmark har imidlertid i årene 1995-2008 været blandt de laveste i OECD. Den svagere produktivitetsudvikling vedrører særligt serviceerhvervene og bygge- og anlægsvirksomhed, mens produktivitetsudviklingen i industrien har holdt momentum.

Danske virksomheders konkurrenceevne overfor udlandet er blevet svækket siden 2000 (hvor euroen og den danske krone imidlertid også var relativt lav over for blandt andet den amerikanske dollar og en række andre valutaer). Det er en udfordring som skærpes af, at produktivitets- 
udviklingen som nævnt har ligget under udlandets. Samtidig er det sandsynligt, at det internationale tilbageslag har medført større fokus på pris som konkurrenceparameter.

Med henblik på at håndtere vækstudfordringen har regeringen nedsat et vækstforum, der skal rådgive regeringen og bidrage til at analysere og levere svar på udfordringerne for vækst.

Tabel 2

\begin{tabular}{|c|c|c|c|c|c|c|c|}
\hline \multicolumn{8}{|c|}{ Efterspørgsel, import og produktion } \\
\hline & 2009 & 2007 & 2008 & 2009 & 2010 & 2011 & 2012 \\
\hline & \multicolumn{3}{|l|}{ Mia. kr. } & \multicolumn{3}{|c|}{ Realvækst, pct. } & \\
\hline Privat forbrug & 813,6 & 3,0 & $-0,6$ & $-4,5$ & 2,2 & 2,2 & 1,8 \\
\hline Offentligt forbrug & 496,3 & 1,3 & 1,6 & 3,1 & 1,0 & $-0,3$ & 0,3 \\
\hline Offentlige investeringer & 34,1 & $-3,0$ & 0,8 & 4,6 & 9,4 & 9,4 & $-8,1$ \\
\hline Boliginvesteringer & 81,2 & $-6,0$ & $-10,9$ & $-16,9$ & $-13,0$ & 1,5 & 3,0 \\
\hline Erhvervsinvesteringer & 188,4 & 3,9 & $-0,2$ & $-15,8$ & $-7,3$ & 5,0 & 4,1 \\
\hline Lagerinvest. (vækstbidrag) & $-20,3$ & 0,3 & $-0,6$ & $-2,0$ & 1,4 & 0,1 & 0,1 \\
\hline Indenlandsk efterspørgsel & $1.592,9$ & 2,3 & $-1,2$ & $-6,5$ & 1,6 & 1,9 & 1,5 \\
\hline Eksport & 792,8 & 2,8 & 2,8 & $-9,7$ & 4,5 & 3,8 & 3,9 \\
\hline - heraf industrieksport & 340,0 & 2,2 & 4,6 & $-13,0$ & 5,9 & 4,5 & 4,7 \\
\hline Samlet efterspørgsel & $2.385,7$ & 2,5 & 0,1 & $-7,7$ & 2,6 & 2,6 & 2,3 \\
\hline Import & 729,6 & 4,3 & 2,7 & $-12,5$ & 3,7 & 4,4 & 4,2 \\
\hline - heraf vareimport & 459,6 & 2,9 & 0,1 & $-14,9$ & 4,0 & 4,1 & 3,7 \\
\hline Bruttonationalprodukt (BNP) & $1.656,1$ & 1,6 & $-1,1$ & $-5,2$ & 2,0 & 1,7 & 1,5 \\
\hline $\begin{array}{l}\text { Beskæftigelse (1.000 perso- } \\
\text { ner) }\end{array}$ & - & 2.861 & 2.909 & 2.824 & 2.769 & 2.770 & 2.774 \\
\hline $\begin{array}{l}\text { Ledighed, pct. af arbejdsstyr- } \\
\text { ken (DK definition) }\end{array}$ & - & 2,7 & 1,7 & 3,4 & 4,0 & 4,2 & 4,0 \\
\hline $\begin{array}{l}\text { Bruttoledighed, pct. af arbejds- } \\
\text { styrken (DK definition) }\end{array}$ & & 3,5 & 2,5 & 4,5 & 5,8 & 6,0 & 5,7 \\
\hline $\begin{array}{l}\text { Forbrugerprisindeks, pct. } \\
\text { ændring }\end{array}$ & - & 1,7 & 3,4 & 1,3 & 2,3 & 1,7 & 1,7 \\
\hline Timeløn, pct. ændring & - & 4,1 & 4,6 & 3,0 & 2,1 & 2,4 & 2,7 \\
\hline Effektiv kronekurs $(1980=100)$ & - & 103,2 & 105,8 & 107,8 & 104,1 & 104,2 & 104,2 \\
\hline $\begin{array}{l}\text { Bytteforhold, varer, pct. æn- } \\
\text { dring }\end{array}$ & - & 0,5 & 0,4 & 3,2 & $-0,1$ & $-0,7$ & $-0,1$ \\
\hline Betalingsbalancen, mia. kr. & - & 23,0 & 46,2 & 59,0 & 79,0 & 69,0 & 71,1 \\
\hline 3 mdr. pengemarkedsrente & - & 4,9 & 4,9 & 1,5 & 1,2 & 1,6 & 2,2 \\
\hline
\end{tabular}

Kilde: Økonomisk Redegørelse, december 2010 


\section{Finland}

\subsection{Den ekonomiska politiken}

Till följd av den ekonomiska krisen har Finlands i princip starka offentlig ekonomi försämrats kraftigt, 2009 med så mycket som 12 miljarder euro, dvs. 7 procentenheter i relation till BNP. De automatiska stabilisatorerna har tillåtits agera fritt och dessutom har de beslutsbaserade stimulansåtgärderna försämrat den offentliga ekonomins finansiella situation.

Även om ekonomin vänder något uppåt i år fördjupas underskottet i den offentliga ekonomin ytterligare, eftersom förändringar i konjunkturläget syns med ett visst dröjsmål i den offentliga ekonomin. Underskottet beräknas vara något större än de $3 \%$ i relation till BNP, som anges i EU:s stabilitets- och tillväxtpakt. Även i år stödjer finanspolitiken ekonomisk tillväxt.

Under 2010 och 2011 tas de första stegen mot balans i den offentliga ekonomin. I och med de avtalade höjningarna av mervärdesskatten, energiskatten samt godis- och läskedrycksskatten håller finanspolitiken på att förändras från att ha varit stimulerande i en åtstramande riktning.

Den gryende ekonomiska tillväxten och de skattehöjningar som genomförs ökar totalinkomsterna inom den totala ekonomin och ökningen av de totala utgifterna begränsas av bl.a. de jämförelsevis återhållsamma löneförhöjningarna och det stegvisa avvecklandet av stimulansåtgärderna. Den offentliga ekonomins situation förbättras nästa år men den fortsätter att uppvisa ett kännbart underskott, 1,4 \% i relation till totalproduktionen.

Statsfinanserna utgör den konjunkturkänsligaste delen av den offentliga ekonomin. Den försämrade ekonomiska aktiviteten har synts kraftigast i intäkterna av samfunds-, kapitalinkomst- och bilskatterna, som sjönk drastiskt i fjol. Även om den ekonomiska tillväxten återhämtar sig, fortsätter statsfinansernas finansiella situation att försämras i år. Underskottet uppgår redan till nästan $6 \%$ av bruttonationalprodukten. Nästa år minskar underskottet tack vare den snabbare ekonomiska tillväxten och skattehöjningarna till drygt $4 \%$ i relation till totalproduktionen.

Den offentliga ekonomins s.k. EMU-skuld uppgår i slutet av året till cirka 88 miljarder euro. Eftersom den offentliga ekonomin fortsätter att uppvisa ett underskott växer också den offentliga skulden och överskrider som det ser ut nu 100 miljarder euro 2012. Trots att Finlands offentliga skuldförhållande fortfarande är relativt lågt vid en jämförelse mellan EUländerna, växer skulden i oroväckande takt. Som det ser ut nu växer statsskulden från 2008 till 2012 med nästan 40 miljarder euro till över 90 miljarder euro, dvs. med 18 procentenheter i relation till totalproduktionen. Ränteutgifterna för statsskulden uppgår i år till knappt 2,5 miljarder euro. 
De skador som den ekonomiska krisen orsakat kommunekonomin tycks bli mindre än befarat. Kommunernas ekonomi förblir även i år stramare än normalt eftersom intäkterna av kommunalskatten inte ökar till följd av det svaga sysselsättningsläget. Statens åtgärder, bl.a. höjningen av utdelningen av samfundsskatten och slopandet av folkpensionsavgiften, har stärkt kommunekonomin avsevärt under den akuta krisen.

Socialskyddsfonderna i sin helhet uppvisar ett klart överskott. Socialskyddsfonderna finansiella överskott förväntas bli något starkare i år jämfört med föregående år, dvs. 5 miljarder euro, vilket är 2,8 \% i relation till totalproduktionen. Överskottet finns endast hos arbetspensionsfonderna, med vilka man förbereder sig på de växande pensionsutgifterna när befolkningen blir äldre.

\subsection{Den ekonomiska utvecklingen}

Recessionen 2009 är i ljuset av de nuvarande, fortfarande preliminära statistikuppgifterna en av de djupaste i Finlands ekonomiska historia. I ljuset av Statistikcentralens förhandsuppgifter skulle årsförändringen i BNP för 2009 vara - $8 \%$, vilket motsvarar ett ras på cirka 13,3 miljarder euro från 2008. Exporten av varor och tjänster föll med en femtedel, och de privata investeringarna minskade med över $17 \%$. Den privata konsumtionen krympte också rätt kraftigt, med nästan 2 \% från 2008.

Recessionen, som började som en finanskris i Förenta staterna och därifrån spred sig till den internationella ekonomin, innebar en temporär chock som påverkade efterfrågan. Sådana öppna ekonomier som Finland har just inga möjligheter att skydda sig mot globala chocker. Fjolårets recession är ett bra exempel på detta, eftersom vår ekonomi var i bra skick före krisen. Inga inhemska ekonomiskpolitiska åtgärder spelade någon avgörande roll för att recessionen nådde Finland.

Världsekonomin har vänt uppåt framför allt tack vare de ekonomier som är stadda i utveckling. I ljuset av den allra senaste statistiken tycks den snabbaste tillväxtfasen vara förbi även inom dessa områden, men tillväxten mot slutet av året kommer ändå att vara stark jämfört med föregående år. Det för Finland viktiga euroområdet kommer att gynnas av det starka draget från världsekonomin och i synnerhet världshandeln mot slutet av året och i början av nästa år.

Återgång till en hållbar tillväxt förutsätter att förtroendet stärks ytterligare och att den marknadsledda tillväxten kommer i gång. Prognosen utgår ifrån att den privata marknadsledda tillväxten håller på att komma i gång i världen, men man kommer inte att nå upp till de ypperliga tillväxtsiffror som föregick krisen av flera olika orsaker. Till dem hör t.ex. den fortsatta osäkerheten på finansmarknaden, de offentliga ekonomiernas dåliga finansiella situation, industriländernas låga produktivitetsutveckling och den höga arbetslösheten. 
Den huvudsakliga prognosrisken kommer åter en gång från finansmarknaden. Även om situationen har lugnat ner sig sedan i våras och Europeiska kommissionens stresstester av bankerna har bidragit till att minska osäkerheten på marknaden, ligger risktilläggen fortfarande på hög nivå. I den nuvarande situationen reagerar finansmarknaden också lätt på dåliga nyheter. När man ska uppskatta den ekonomiska utvecklingen under de närmaste åren måste man också beakta den roll som stimulansen och slutet på den spelar. På grund av de offentliga ekonomiernas dåliga situation kan stimulansen inte fortsätta med nuvarande styrka även om den ekonomiska utvecklingen på nytt skulle ta en sämre vändning. Dessutom skulle stimulansens effekt ifrågasättas.

Bakom prognosen ligger på normalt sätt en mängd antaganden. Eurons externa värde antas förbli stabilt under hela prognosperioden. Till följd av den livligare världshandeln antas priserna på olja och andra råvaror stiga måttfullt till 2012. När det gäller penningpolitiken, åtminstone inom euroområdet, har man stegvis börjat upplösa de exceptionella arrangemangen för att trygga likviditeten. Dessutom förväntas en måttfull åtstramning även av den mera traditionella penningpolitiken vilket leder till att marknadsräntorna stiger. Tre månaders Euribor kommer att ligga på drygt $3 \%$ i slutet av 2012.

Tillväxten inom den finländska samhällsekonomin uppskattas i år bli cirka 2 \% och 2011 tilltar tillväxten till knappt 3 \%. Nästa år borde bli det bästa tillväxtåret under prognosperioden, för 2012 avtar tillväxten till 2,6 \%. Bakgrunden till årets tillväxt är i första hand ökningen av den totala efterfrågan. Tillväxtkällan nästa år är i första hand en kraftig exportökning och återhämtningen för de privata investeringarna.

I slutet av prognosperioden stannar totalproduktionen fortfarande drygt $1 \%$ under nivån toppåret 2008. Inte heller industriproduktionen kommer att nå sin tidigare rekordnivå utan ligger 2012 fortfarande på en nivå som är $5 \%$ lägre. Trots att kapacitetsutnyttjandet ökar tros inte kapacitetsgränserna höjas mycket.

I Finland har varuexportens utförsbacke varit kännbart brantare än i andra länder, dvs. Finland har förlorat exportandelar på världsmarknaden. Denna utveckling har blivit den rådande trenden på 2000-talet till följd av Finlands perifera läge, försämrade konkurrenskraft samt de asiatiska länderna alltmer framskjutna position. På grund av att tyngdpunkten i Finlands exportstruktur ligger på investerings- och mellanprodukter syns den livligare världshandeln långsammare i Finland än i många andra länder och den snabbaste tillväxtfasen i exporten infaller också nästa år. År 2011 påskyndas exportökningen till $8 \%$.

Sedan i våras har hushållens förtroende ökat på nytt och ligger över medelvärdet på lång sikt. Det torde bli fart på konsumtionsökningen när läget på arbetsmarknaden så småningom förbättras och konsumtionen under hela året torde öka med ett par procent från i fjol. Hushållens inkomstutveckling förbättras när arbetsmarknaden återhämtar sig, inkomstökningen påskyndas 
och förmögenhets- och företagarinkomsterna blomstrar upp. Trycket på att höja konsumentpriserna är litet och statens inkomstbeskattning torde inte skärpas varken i år eller nästa år, så utgångspunkterna för ökade realinkomster är gynnsamma. När konsumenternas förtroende för framtiden dessutom är starkt torde konsumtionen fortsätta att växa även nästa och därpå följande år. År 2012 försnabbas konsumtionsökningen ytterligare från de cirka $2 \%$ som uppskattats för nästa år.

Nedgången i investeringarna tycks bli kortvarig. Investeringsprognosen för 2010 är visserligen fortfarande på nedåtgående, men minskningen blir klart mindre än vad som uppskattades tidigare. Skillnaderna mellan olika sektorer och typer av investeringsvaror är dock fortfarande stora; den starka uppgången för bostadsinvesteringarna kompenserar nedgången i fråga om andra varutyper. De påverkas kännbart av såväl den penningsom den finanspolitiska stimulansen, som är i kraft med nästan full styrka även i år. Den låga räntenivån stödjer både investeringar i nya bostäder och ombyggnader, men efterfrågan har också ökat av det konjunkturella reparationsunderstödet samt de lindrigare villkoren för den s.k. mellanstegsmodellen för statsstödda hyresbostadsinvesteringar. De privata investeringarna börjar öka redan i år, däremot krymper de offentliga investeringarna på grund av den kommunala sektorns nedskärningar.

\subsection{Utsikterna på medellång sikt}

Produktionen kommer inte längre att återgå till samma tillväxtspår på medellång sikt som efter depressionsåren i början av 1990-talet. Även om nivån för det föregående toppåret 2008 skulle uppnås inom några år, kommer tillväxten på grund av flera faktorer att förbli långsammare än under 1990-talet. Medan konkurrenskraften vid den tiden förbättrades avsevärt tack vare devalveringen av marken, har vår priskonkurrenskraft däremot snarare försvagats under den senaste tiden. Något likadant Nokia-fenomen som uppkom i slutet av 1990-talet finns inte längre inom synhåll. Det är sannolikt att den senaste ekonomiska krisen på ett varaktigt sätt sänkt nivån för den potentiella produktionen som motsvarar fullt utnyttjande av resurserna. Den arbetsföra befolkningen börjar minska i takt med den demografiska förändringen. Recessionen har dessutom troligtvis påskyndat pensionsavgångar som har samband med ändringen i åldersstrukturen.

Den viktigaste enskilda faktorn som förklarar den ekonomiska tillväxten i Finland efter depressionen i början av 1990-talet har varit ökningen av produktiviteten. Förstärkningen av elektronikindustrins ställning har medverkat till denna utveckling. Branschens tillväxtmöjligheter har emellertid försvagats avsevärt i Finland. Förändringen av befolkningens åldersstruktur kommer förmodligen att öka på servicesektorns betydelse för ekonomin. Det är oundvikligt att serviceproduktionens produktivitetsutveckling kommer att förbli svagare jämfört med den traditionella fabriks- 
industrin. Produktivitetsökningen beräknas därför förbli klart svagare under de närmaste åren jämfört med tidigare år.

Den demografiska förändringen återspeglas i det första skedet i minskningen av den arbetsföra befolkningen. Statistikcentralens befolkningsprognos visar att antalet arbetsföra kommer att minska tydligt under de följande fem åren. Arbetskraftsutbudet kommer alltså oundvikligen att krympa under detta årtionde. Recessionen kommer sannolikt att påskynda den minskning av arbetskraften som beror på åldrandet, eftersom en stor del av dem som blivit arbetslösa under krisen och som närmar sig pensionsåldern lämnar troligtvis slutligen utanför arbetskraften. Ökningen av antalet sysselsatta kommer så småningom att börja avta på grund av att arbetskraftsresurserna krymper.

Läget för den offentliga ekonomin kommer inte heller att förbättras på samma sätt som efter depressionen på 1990-talet. Den offentliga ekonomin hade ett underskott under 1991-1997. Den medellånga grundtrenden antyder att det offentliga underskottet varar under 2009-2015. Den offentliga ekonomin kommer också att ha ett fortsatt underskott om inga nya balanserande beslut fattas, bl.a. eftersom tillväxten beräknas förbli tämligen svag jämfört med slutet av 1990-talet och 2000-talet. Uppskattningen som följer grundtrenden inkluderar inte några särskilda utgiftsminskningar eller ändringar i skattegrunderna.

Tabell 3

\begin{tabular}{|c|c|c|c|c|c|}
\hline \multicolumn{6}{|c|}{ Nyckeltal för Finlands ekonomi. Procentuell förändring ${ }^{1}$} \\
\hline & Mdr. euro 2009 & 2009 & 2010 & 2011 & 2012 \\
\hline \multicolumn{6}{|l|}{ Fasta priser } \\
\hline Hushållens konsumtionsutgifter (=privata) & 94 & $-1,9$ & 2,0 & 2,0 & 2,7 \\
\hline Offentliga konsumtionsutgifter & 43 & 1,2 & 0,4 & 0,7 & 0,7 \\
\hline Fasta bruttoinvesteringar & 33 & $-14,7$ & $-0,1$ & 5,0 & 3,0 \\
\hline Näringsliv & 18 & $-17,1$ & $-7,9$ & 5,0 & 3,5 \\
\hline Bostäder & 10 & $-13,4$ & 15,0 & 6,0 & 2,0 \\
\hline Myndigheter & 5 & 6,1 & $-3,8$ & $-0,7$ & 0,5 \\
\hline Lagerinvesteringar $^{2}$ & -2 & & & & \\
\hline Total inhemsk efterfrågan & 168 & $-5,9$ & 0,5 & 2,4 & 2,3 \\
\hline Export & 64 & $-20,3$ & 6,1 & 8,0 & 5,0 \\
\hline Import & 60 & $-18,1$ & 4,0 & 7,3 & 4,3 \\
\hline Bruttonationalprodukt & 171 & $-8,0$ & 2,1 & 2,9 & 2,6 \\
\hline Sysselsättning, personer & $\ldots$ & $-2,9$ & $-0,5$ & 1,3 & 1,3 \\
\hline Arbetslöshet (\% av arbetskraften) & . & 8,2 & 8,6 & 8,2 & 7,9 \\
\hline Konsumtionsprisindex & . & 0,0 & 1,5 & 2,5 & 2,0 \\
\hline Lön ${ }^{3}$ & . & 4,0 & 2,6 & 2,8 & 3,0 \\
\hline Effektiv valutakurs ${ }^{4}$ & . & & & & \\
\hline Bytesförhållande & . & 0,6 & $-2,2$ & $-1,8$ & $-1,6$ \\
\hline Bytesbalans (\% av BNP) & . & 1,3 & 1,4 & 1,1 & 0,7 \\
\hline 3-månaders penningmarknadsränta (nivå) & . & 1,2 & 1,0 & 2,0 & 3,0 \\
\hline
\end{tabular}

1) Beräknat i fasta priser, basår 2000 .

2) Förändring $i \%$ av föregående års BNP.

3) Löneindex.

4) Positivt tal innebär depreciering

Källor: Statistikcentralen och Finansministeriets ekonomiska avdelning (september 2010) 



\section{Norge}

\subsection{Den økonomiske politikken}

Hovedmålet for Regjeringens økonomiske politikk er arbeid for alle og en rettferdig fordeling av goder og byrder. Med utgangspunkt i den nordiske modellen vil Regjeringen fornye og utvikle de offentlige velferdsordningene, bidra til en mer rettferdig fordeling og til et arbeidsliv der alle kan delta. Regjeringen vil legge til rette for økt verdiskaping og utvikling i hele landet, innenfor rammer som sikrer at framtidige generasjoners muligheter for å dekke sine behov ikke undergraves. En slik bærekraftig utvikling krever en ansvarlig politikk med vekt på natur- og miljøhensyn, en langsiktig forvaltning av nasjonalformuen, et opprettholdbart pensjonssystem, et velfungerende næringsliv og en sterk og effektiv offentlig sektor.

Handlingsregelen for budsjettpolitikken innebærer en gradvis innfasing av petroleumsinntektene i norsk økonomi, om lag i takt med utviklingen i forventet realavkastning av Statens pensjonsfond - Utland, anslått til 4 pst. Samtidig skal bruken av petroleumsinntekter det enkelte år tilpasses konjunktursituasjonen. I år med konjunkturtilbakeslag åpnes det for å bruke mer enn forventet fondsavkastning, mens bruken bør ligge under forventet realavkastning i år med høy aktivitet og press i økonomien. På denne måten bidrar budsjettpolitikken til en stabil økonomisk utvikling både på kort og lang sikt. Pengepolitikken skal sikte mot stabilitet i den norske krones nasjonale og internasjonale verdi. Den operative gjennomføringen av pengepolitikken skal rettes inn mot lav og stabil inflasjon, definert som en årsvekst i konsumprisene som over tid er nær 2,5 pst. Av forskriften følger det at pengepolitikken skal bidra til å stabilisere utviklingen i produksjon og sysselsetting og til stabile forventninger om valutakursutviklingen. Budsjett- og pengepolitikken må virke sammen for å bidra til en balansert utvikling i norsk økonomi.

Hovedoppgaven for den økonomiske politikken i 2009 og 2010 har vært å bekjempe virkningene av finanskrisen på sysselsetting og arbeidsledighet i Norge. Finanspolitikken ble på denne bakgrunn dreid kraftig i ekspansiv retning, noe som brakte bruken av oljeinntekter opp på et nivå vesentlig over 4-prosentbanen. Også pengepolitikken ble raskt lagt om i ekspansiv retning, og Norges Banks styringsrente ble fra høsten 2008 og fram til sommeren 2009 redusert til 11/44 pst., det laveste nivået noensinne. Siden da er styringsrenten satt opp med $3 / 4$ prosentpoeng til 2 pst., noe som fortsatt er et svært lavt nivå. Norges Bank har varslet at renten gradvis vil bli satt opp mot et mer normalt nivå. I rentebanen fra pengepolitisk rapport 3-2010, som ble publisert i forbindelse med rentemøte 27. oktober, antyder Norges 
Bank at neste renteøkning kommer nærmere sommeren 2011 og at styringsrenten i gjennomsnitt vil være 3 pst. i 2. kvartal 2012.

Den økonomiske politikken har lykkes godt. Norge har klart seg bedre enn de fleste andre industriland gjennom krisen. Mens BNP falt med over 3 pst. hos våre handelspartnere i 2009, var nedgangen i norsk fastlandsøkonomi bare 1,4 pst. Arbeidsledigheten har bare økt svakt, og ligger fortsatt under det gjennomsnittlige nivået for de siste 20 årene og vesentlig under nivåene i de fleste andre industriland. Utfordringen framover er å ta vare på de gode resultatene, opprettholde handlefriheten i finanspolitikken og unngå et for høyt kostnadsnivå.

Aktiviteten i norsk økonomi er på vei opp, og i Nasjonalbudsjettet 2011 ble veksten i fastlandsøkonomien anslått til 1,7 pst. i 2010 og 3,1 pst. i 2011. Med utsikter til vekst over trend i 2011 og fortsatt lav arbeidsledighet har Regjeringen funnet det riktig å stramme til i Statsbudsjettet for 2011, og redusere avstanden til 4-prosentbanen. I budsjettforslaget er oljepengebruken holdt reelt uendret fra 2010 til 2011, målt ved det strukturelle, oljekorrigerte budsjettunderskuddet. Målt i forhold til trend-BNP for Fastlands-Norge tilsvarer dette en budsjettinnstramming på 0,2 pst. Både hensynet til de statlige finansene på lang sikt, og hensynet til pengepolitikken, kronekursen og konkurranseutsatt sektor, tilsier en slik innretning av 2011-budsjettet. Merbruken av oljeinntekter utover 4prosentbanen ble med det redusert fra 19 mrd. kroner i 2010 til 7,4 mrd. kroner i 2011.

\subsection{Den økonomiske utviklingen}

Opphentingen i norsk økonomi etter finanskrisen og det internasjonale tilbakeslaget har fortsatt i inneværende år. Lavere veksttakt i det private forbruket og eksporten av tradisjonelle varer bidro imidlertid til å dempe aktivitetsvekten på nyåret, og BNP for Fastlands-Norge økte bare med 0,2 pst. i 1 . kvartal, etter å ha økt med om lag 1/2 pst. både i 3. og 4. kvartal i fjor. I 2. kvartal tok veksten seg igjen opp til 1/2 pst., trukket opp av høyere realinvesteringer både i petroleumssektoren, offentlig forvaltning og i fastlandsbedriftene. Informasjon fra Norges Banks regionale nettverk og Statistisk sentralbyrås konjunkturbarometer indikerer at aktivitetsoppgangen fortsatte i 3. kvartal. Videre vekst i industriproduksjon og husholdningenes varekonsum peker i samme retning.

Privat konsum er ventet å være en av de viktigste drivkreftene bak videre aktivitetsoppgang i norsk fastlandsøkonomi framover. Etter svak utvikling i første halvår, der konsumet bare økte med $1 \frac{1}{2}$ pst. i 1 . kvartal for så å falle tilsvarende tilbake i 2 . kvartal, ser konsumveksten nå ut til å være på vei opp igjen. Ifølge SSB's varekonsumindeks økte varekonsumet, som utgjør vel halvparten av samlet privat konsum, med 1,1 pst. i 3. kvartal. Oppgangen har bl.a. kommet sammen med økt optimisme i hus- 
holdningssektoren. TNS Gallups trendindikator steg markert i 3. kvartal, etter at sammenhengende oppgang i fem kvartaler ble brutt av et fall i 2. kvartal. Indikatoren var med det tilbake på nivå fra før finanskrisen, og innebærer at en klar overvekt av befolkningen er positive til den videre økonomiske utviklingen. Sammen med lave renter, fortsatt lav arbeidsledighet og en høy sparerate gir økt forbrukertillit grunn til å vente at oppgangen vil fortsette framover. I Nasjonalbudsjettet 2011 er privat konsum anslått å øke med 23/4 pst. i 2010 og 31/2 pst. i 2011. Veksten i disponibel realinntekt ble anslått noe lavere, slik at spareraten avtar fra 7,5 pst. i 2009 til anslagsvis vel 61/2 pst. i 2010 og om lag 6 pst. i 2011. Usikkerheten i anslagene er imidlertid stor, og det kan ikke utelukkes at spareraten avtar raskere enn dette. Særlig dersom den høye sparingen i første halvår var forsikringsmotivert, og i hovedsak kan knyttes til den økte usikkerheten internasjonalt, kan spareraten avta raskere enn anslått. Dersom den høye sparingen derimot skyldes et mer strukturelt behov for å bygge ned gjeld, kan nedgangen i spareraten skje mer gradvis.

Etter at finanspolitikken ble dreid kraftig i ekspansiv retning i kjølevannet av finanskrisen, har offentlig etterspørsel gitt sterke vekstimpulser mot fastlandsøkonomien. Disse impulsene vil avta framover. I Nasjonalbudsjettet for 2011 er offentlig konsum anslått å øke med hhv. om lag 23/4 og 2 pst. i 2010 og 2011, etter en vekst på om lag 43/4 pst. i 2009. Veksten i offentlige investeringer ble anslått til hhv. 313/4 og 5 pst. i de to årene, ned fra 7 pst. i 2009.

Bedriftenes investeringer i fast kapital svinger kraftig med konjunkturene. Foreløpige nasjonalregnskapstall tyder på at den markerte nedgangen i investeringene i fastlandsbedriftene siden høsten 2008 er nå i ferd med å bunne ut. Etter å ha falt kraftig gjennom 2009 og inn i 2010, økte investeringene betydelig i 2. kvartal i år. Produksjonsoppgang, økt lønnsomhet i bedriftene og lettere tilgang på finansiering gir grunn til å vente at den positive utviklingen fortsetter framover. Både Norges Banks utlånsundersøkelse og kredittstatistikken viser oppgang i foretakenes låneetterspørsel. Kapasitetsoppbyggingen i forkant av finanskrisen var imidlertid svært høy, og kan isolert sett tilsi et noe mer begrenset behov for nyinvesteringer. I Nasjonalbudsjettet 2011 ble det lagt til grunn en nedgang i investeringene $\mathrm{i}$ fastlandsbedriftene på om lag 4 pst. i 2010 og en oppgang på vel 31/4 pst. i 2011. Også petroleumsinvesteringene, som har gitt betydelige vekstimpulser til fastlandsøkonomien de siste årene, ligger an til å øke neste år. På bakgrunn av bl.a. informasjon fra SSBs investeringstelling for 3. kvartal ble disse investeringene i Nasjonalbudsjettet 2011 anslått å øke med om lag 6 pst. neste år, etter en nedgang på anslagsvis 33/4 pst. i år.

Eksporten av tradisjonelle varer har vært om lag uendret $\mathrm{i}$ årets tre første kvartaler, etter at en klar oppgang i fjor høst hentet inn igjen mye av nedgangen som fulgte av krisen. Framover ventes eksportveksten å ta seg opp, i lys av den sterke utviklingen hos viktige handelspartnere som Sverige og Tyskland samt flere land i Asia. Eksportvolumet av tradisjo- 
nelle varer ble i Nasjonalbudsjettet 2011 anslått å øke med om lag hhv. 51/2 og 51/4 pst. i 2010 og 2011.

Samlet sett ble veksten i BNP for Fastlands-Norge i Nasjonalbudsjettet 2011 anslått å ta seg opp fra 1,7 pst. i 2010 til 3,1 pst. 2011. Statistikk som er kommet etter framleggelsen av budsjettet er godt i tråd med anslagene. Usikkerheten knyttet til den videre økonomiske utviklingen er imidlertid fortsatt stor.

De relativt sett beskjedene utslagene av finanskrisen i norsk økonomi gjenspeiles også i arbeidsmarkedet. Både nedgangen i sysselsettingen og oppgangen i arbeidsledigheten har vært liten i internasjonal sammenheng. Etter en oppgang på hele 300000 personer gjennom de foregående fem årene gikk sysselsettingen ned med nærmere 40000 personer fra 3. kvartal 2008 til 3. kvartal 2009. Etter dette har nedgangen bremset kraftig opp, og i følge tall fra AKU holdt sysselsettingen seg relativt stabil fra 2. til 3. kvartal i år. Også ledigheten holdt seg stabil gjennom årets seks første måneder, men avtok i 3. kvartal, til 3,4 pst. I Nasjonalbudsjettet 2011 ble det lagt til grunn at sysselsettingen øker forsiktig mot slutten av året og gjennom neste år, mens arbeidsledigheten ble anslått å holde seg relativt stabil, og som årsgjennomsnitt være hhv. 3,5 og 3,6 pst. i 2010 og 2011. Dette er vesentlig lavere enn det historiske gjennomsnittet.

Et mindre stramt arbeidsmarket har bidratt til lavere lønnsvekst. På bakgrunn av årets lønnsoppgjør, og i lys av det høye kostnadsnivået i Norge og den usikre situasjonen internasjonalt, ble lønnsveksten anslått til 311/4 i både 2010 og 2011 i Nasjonalbudsjettet 2011, ned fra 4,2 pst. i 2009.

Lavere lønnsvekst, prisfall på importerte konsumvarer og lavere vekst i husleiene har trukket prisveksten ned i inneværende år. Tolvmånedersveksten i konsumprisene justert for avgiftsendringer og utenom energivarer (KPI-JAE) falt fra 2,3 pst. i januar til 0,9 pst. i september. Høye elektrisitetspriser har likevel bidratt til at veksten i konsumprisene samlet sett (KPI) har vært høyere. I Nasjonalbudsjettet 2011 ble veksten i KPI anslått til 21/2 pst. i 2010 og 13/4 pst. i 2011, mens veksten i KPI-JAE ble anslått til $1 \frac{1 / 2}{2}$ og 2 pst. i de to årene.

\subsection{Utsiktene på mellomlang sikt}

Bruttoproduktet falt vesentlig mer enn timeverkene i kjølevannet av finanskrisen andre halvår 2008 og gjennom 2009. Dette resulterte i en betydelig nedgang i arbeidskraftsproduktiviteten. Mens produktivitetsveksten var på 2,2 pst. som gjennomsnitt i årene 2004-2007, avtok den til -0,6 pst. som gjennomsnitt for de to årene 2008 og 2009. Fallet i arbeidsproduktiviteten har trolig sammenheng med at bedrifter har villet holde på kompetanse og kapasitet i påvente av bedrede markedsforhold. I Nasjonalbudsjettet 2011 ble produktivitetsveksten anslått å ta seg opp til 2 pst. som gjennomsnitt for 2010 og 2011. I årene 2012-2015 ble det lagt til 
grunn en vekst i timeverkene på om lag 3/4 pst. per år, og med en produktivitetsvekst på $1 \frac{1}{2}-2$ pst. kunne veksten i produksjonskapasiteten i økonomien anslås til om lag $2 \frac{1}{2} \mathrm{pst}$. i denne perioden. Ledigheten ventes å stabilisere seg på et nivå godt under det gjennomsnittlige nivået for de siste 20 årene. 



\section{Sverige}

\subsection{Recent developments and economic policy}

The Swedish economy is still in an economic slowdown with low resource utilisation and high unemployment. The recovery is nevertheless both broader and more rapid than forecast in the 2010 Spring Fiscal Policy Bill. Both output and employment have increased at a good pace during the first half of 2010. Behind the change are an expansive economic policy and a rapid turnaround in the international demand for Swedish exports. These developments have helped make households and businesses increasingly optimistic and the growth rates of consumption and investment have picked up. This year and in the coming years, the Swedish economy will continue its recovery owing to strong domestic demand, improvement in the international economic situation, the Government's reforms and the continuation of an expansive monetary policy. Resource utilisation in the Swedish economy is expected to return to a balanced level at the end of 2014.

At the same time, there is a significant risk of a worse outcome caused by the situation of government finances in other countries. Because of the extensive extraordinary measures taken by governments and central banks in autumn 2008, a financial meltdown could be averted. Subsequently, the functioning of the markets has improved step by step, but significant risks remain. In spring 2010, uncertainty increased again on account of the problems in government finances in several countries. The measures taken in connection with the crisis in government finances and the EU stress test of European banks have, however, helped reduce the uncertainty about the European banking system. There are, however, still risks associated with the funding of European banks and businesses, which are linked to large government financing requirements in the future, particularly in countries with large budget deficits.

The financial market situation is now on the whole more stable, but there are reasons for continued vigilance. Weaker growth in countries where there are substantial problems with government finances risks resulting in a slower economic recovery in Sweden and in the worst case, to a second downturn.

\subsection{The outlook}

The Swedish economy has grown strongly in recent times and forwardlooking indicators point to the continuation of a strong and broad based 
recovery. Both domestic demand and exports are important in driving the recovery forward. Despite the strong recovery in 2010, however, resource utilisation in the economy is low.

The prospects for a continued strong and broad recovery are also good in the coming years. A continuation of the expansive monetary policy combined with the Government's reforms, for example, the in-work tax credit, the increased central government grants to local government and reduced tax for pensioners, helps increase household real disposable income. An increase in employment also has a positive effect on consumption and investment. At the same time, the severe economic slowdown has led households to increase their precautionary saving, which has resulted in a historically high savings ratio. In the coming period, precautionary savings are expected to decline as the labour market improves, which will contribute to a relatively strong increase in consumption in the next few years.

The growth in world trade will contribute to an increased demand for Swedish exports. At the same time, investment will increase in line with rising capacity utilisation. In total, GDP is expected to rise by 4.8 per cent in 2010 and by 3.7 per cent in 2011.

The recovery will continue in 2012-2014 and resource utilisation will come close to being in balance at the end of 2014. Because the recovery is progressing much more rapidly than predicted earlier, the permanent effects of the crisis are expected to be less than previously anticipated. As a result, GDP may grow more rapidly and reach a higher level without resource utilisation becoming strained.

Tabel 4

Key indicators

Percentage change, unless otherwise stated - Outcome 2009, forecast 2010-2014

\begin{tabular}{lrrrrrr}
\hline & $\mathbf{2 0 0 9}$ & $\mathbf{2 0 1 0}$ & $\mathbf{2 0 1 1}$ & $\mathbf{2 0 1 2}$ & $\mathbf{2 0 1 3}$ & $\mathbf{2 0 1 4}$ \\
\hline GDP & -5.1 & 4.8 & 3.7 & 3.4 & 3.3 & 2.8 \\
Productivity $^{1.2}$ & -2.6 & 2.8 & 2.5 & 2.3 & 1.8 & 1.6 \\
Hours worked $^{2}$ & -2.6 & 1.9 & 1.1 & 1.4 & 1.5 & 1.3 \\
Employed $^{3}$ & -2.1 & 1.0 & 1.1 & 1.2 & 1.3 & 1.2 \\
Unemployment $^{4}$ & 8.3 & 8.4 & 8.0 & 7.4 & 6.7 & 6.0 \\
GDP gap $^{5}$ & -5.7 & -3.3 & -2.5 & -1.6 & -1.1 & -0.5 \\
Wages $^{\text {CPI }}$ & 3.4 & 2.5 & 2.6 & 3.1 & 3.3 & 3.4 \\
\hline
\end{tabular}

In the economy as a whole.

${ }^{2}$ Calendar adjusted.

${ }^{3}$ Aged 15-74.

${ }^{4}$ Percentage of the labour force aged $15-74$

${ }^{5}$ Percent of potential GDP.

${ }^{6}$ Annual average.

Sources: Statistics Sweden, National Mediation Office and Ministry of Finance

The strong increase in output and the growing optimism in the business sector contribute to rising employment and increasingly positive recruitment plans. Employment in the service sector had already turned upwards 
in autumn 2009 and has continued to increase in 2010. In manufacturing, both output and employment began to rise early in 2010. Forwardlooking indicators such as recruitment plans and newly registered job vacancies point to a continuing rise in employment in the autumn.

As demand and output rise in the coming years, employment and the number of hours worked will continue to increase, particularly in the service sector. In total, the number of people employed is expected to rise by about 220000 from 2010 to 2014 as a result of the economic recovery, the Government's policy and an increase in the working-age population.

Unemployment will thus go down. The decline will, however, be moderate in the next few years because the labour force will continue to grow for the same reasons that employment is rising. Unemployment is expected to total 8.4 per cent in 2010 and thereafter fall to 6.0 per cent by 2014. As a result of the low resource utilisation, both prices and wages are expected to rise slowly in the next few years.

In spite of the recent positive developments, there is still great uncertainty about the future course of the business cycle. It is also too early to say how the crisis has affected the functioning of the economy and thus how high long-term sustainable growth will be. The risks for a weaker development than in the base scenario are higher than the probability of a more favourable development.

There is a substantial risk that the problems in government finances in other countries will slow down the international recovery more than expected in the base scenario. The problems in countries with large budget deficits may make households and companies in these countries more cautious because they know that large fiscal consolidation may lie ahead. Such a development would result in lower economic growth and a weaker labour market internationally. It could also slow down Sweden's recovery, for example through lower export growth.

In the worst case, the problems in government finances will create renewed financial market turmoil leading to developments similar to those in autumn 2008. In such a situation, it would be substantially more expensive and difficult for households and companies to borrow and for highly indebted countries to roll over their loans. This would lead to significantly weaker growth internationally, particularly in Europe, including Sweden.

But it is also conceivable that the recovery will be faster than foreseen in the base scenario. Forward-looking indicators for both households and companies are very positive and if these expectations are realised, the recovery could be stronger in autumn 2010. In such a scenario, there is a risk that labour shortages will occur in some sectors in the next few years. 



\section{Island}

\subsection{Recent development}

From 2004 to 2007, Iceland's economy boomed, driven by capital inflows. Early in the decade, the newly privatized and deregulated banks rapidly expanded their lending and balance sheets, facilitated by easy access to foreign funding. The abundant and cheap credit fueled a domestic investment and consumption boom, rapid growth of asset prices, rising inflation, and a burgeoning current account deficit. This pattern was common to many countries, but the boom in Iceland stood out for its magnitude.

Policies failed to counter the growing imbalances, and vulnerabilities built up. Financial sector supervision did not detect growing banking sector risks. Fiscal policy fed the boom through a series of tax cuts, which reduced the structural fiscal balance. The central bank responded by raising interest rates, which helped contain inflation by appreciating the króna, but this also contributed to a carry trade and induced households and enterprises to borrow in foreign currencies. Towards the end of the boom period, gross external debt had increased to over 600 percent of GDP, Iceland's net international position turned negative, and corporations and households faced heavy debt burdens, with elevated exposure to foreign exchange and inflation risks. Short-term external obligations had soared, and the CBI was unable to keep up, with reserve coverage falling under 10 percent of short term debt by 2007.

The global banking crisis in late 2008 rapidly exposed Iceland's vulnerabilities, leading to a deep financial and economic crisis. The three large commercial banks had insufficient liquidity to cope with global interbank funding pressures. They proved too big to save, and collapsed in the span of a week. Investors rushed to exit, the króna tumbled, inflation soared, domestic demand and output collapsed, and imports shrank abruptly. The remaining large financial institutions in Iceland would ultimately fail, along with a number of firms in the non-financial sector.

The crisis left Iceland saddled with high external and public debt, threatening a debt crisis. Iceland emerged from the crisis with external debt of 300 percent of GDP, down from 605 percent pre-crisis, but still very high. Projected public sector debt soared from 30 to over 125 percent of GDP, mainly because of the impact of the recession on public finances, the need to recapitalize the banking system, crisis-related central bank losses, and foreign deposit insurance requirements (which the authorities have agreed to cover pending agreement on details, but have not accepted as sovereign debt; this still unresolved Icesave dispute is 
now with the European Surveillance Authority, which has issued a preliminary finding that there is a sovereign obligation, but the dispute is expected to continue up to the EFTA court). With the impact of the crisis on debt, CDS spreads initially soared to close to $1000 \mathrm{bps}$, reflecting market fears.

Iceland's IMF supported program, initiated after the crisis, has cushioned the economy and allowed for a gradual unwinding of imbalances. Indeed despite the severity of the shock, the recession in Iceland has been less severe than expected, and no worse than in other hard-hit countries. A brisk response of net exports has been key factor, and to this end a combination of interests rate policy, capital controls and private sector wage restraint has helped stabilize the exchange rate at a competitive level, and tame the overshooting that could have worsened balance sheet impacts. Private consumption has also held up better than expected supported by an informal payment freeze on mortgages, and the operation of automatic fiscal stabilizers.

The IMF program has also rebuilt financial sector stability, and deflected a government debt crisis. In the financial sector, deposit runs have been avoided, helped by the government's explicit full deposit guarantee and the capital controls regime. New banks have been set up with the domestic assets and liabilities of the failed banks. They have been recapitalized, with the exception of Byr and Keflavik savings banks (which were only intervened in April), and a few small savings banks. The process has taken longer than expected due to difficulties in valuing assets transferred. A process of restructuring and some downsizing lies ahead, called for by lingering imbalances and high levels of non-performing loans on banks' books. Iceland also remains overbanked, with the core of the problem in the large number of inefficient smaller savings banks.

Government debt dynamics are being rapidly brought under control. After the initial expansion of the deficit to cushion the economy, the authorities have stuck to an ambitious adjustment path calibrated on Nordic experience. Over 7 percent of GDP in fiscal measures have been taken to date, and the deficit has been reined in from the 14 percent of GDP projected in mid 2009, to a projected 9 percent of GDP in 2010. CDS spreads on government debt have now dropped to around $300 \mathrm{bps}$.

Balance sheets are slowly being repaired. Concerning overall external debt, the public position has improved through asset and liability management transactions, including repurchase of outstanding Eurobonds at a discount. The position of the non-financial private sector has gradually improved through debt restructuring agreements with creditors. Regarding overall consumer and corporate debt, progress has been very slow, largely due to delays in setting up effective debt-restructuring mechanisms; problems with coordinating multiple creditors and preventing hold outs (especially amongst second and third lien holders); and problems with take up of existing mechanisms by debtors, as they reportedly hold 
out in the expectation that the government will provide a better debt reduction deal for them. Nonetheless, some 400-500 consumer cases have been completed or are in process out of court, and some 100 cases have been processed through the courts.

Recent developments show an economy still facing headwinds. The economy stabilized towards the end of 2009. However, indicators point to a setback in the first half of 2010; due to the March/April volcanic eruption (taking a temporary but significant toll on tourism); the slowdown in the global recovery (weakening demand for exports and worsening the terms of trade); and from the initial fiscal cutbacks (dampening momentum in private consumption). Inflation has continued to fall, with the 12 month rate in October 3.3 percent. The underlying current account remains in surplus.

The restoration of the financial system is also confronting a new challenge. In June the Supreme Court of Iceland ruled that foreign exchange indexation clauses in loan contracts are illegal, but left open the question of what constituted a foreign exchange indexed loan (banks utilized many different $\mathrm{fx}$ and fx-linked contracts). On $16^{\text {th }}$ of September the Supreme Court ruled on how to amend to the provision of these loans that were declared unlawful during the summer and came to the conclusion that they should bear the lowest interest rates published by the Central Bank of Iceland.

Tabel 5

\begin{tabular}{llrrrrr}
\hline Overview of economic development & & & & & & \\
\hline Economic aggregates & & 2008 & 2009 & 2010 & 2011 & 2012 \\
\hline Private consumption & Annual change, \% & -7.9 & -16.0 & -0.2 & 2.6 & 3.7 \\
Public consumption & Annual change, \% & 4.6 & -1.7 & -3.7 & -4.3 & -2.2 \\
Gross fixed capital formation & Annual change, \% & -20.9 & -50.9 & -4.6 & 14.9 & 24.0 \\
National expenditure & Annual change, \% & -8.9 & -20.7 & -1.9 & 2.4 & 5.0 \\
Exports of goods and services & Annual change, \% & 7.1 & 7.4 & -0.1 & 2.0 & 2.0 \\
Imports of goods and services & Annual change, \% & -18.2 & -24.1 & 2.7 & 2.0 & 6.0 \\
Gross domestic production & Annual change, \% & 1.0 & -6.8 & -3.0 & 1.9 & 2.9 \\
Underlying current account & \% of GDP & -3.9 & 0.4 & 0.8 & 0.6 & 0.2 \\
Unemployment & \% of labour force & 1.6 & 8.0 & 8.2 & 7.3 & 5.6 \\
Real wages & Annual change, \% & -8.1 & -10.1 & -1.6 & 1.4 & 3.4 \\
Inflation & Annual change, \% & 12.4 & 12.0 & 5.4 & 2.3 & 2.5 \\
Nominal ISK/EUR exchange rate & Index & 127.0 & 172.0 & 161.2 & 156.5 & 155.5 \\
Real exchange rate & Annual change, \% & -20.7 & -18.4 & 6.4 & 2.9 & 1.5 \\
\hline
\end{tabular}

Note: Underlying current account is without accrued interest cost of banks in winding-up proceedings and gives more accurate view of actual payments flows and of future payments obligations, The current account in table 1 is on the other hand the official current account,

\subsection{Outlook}

A durable recovery is expected to take hold during the second half of 2010. The expected pattern of recovery has not changed, and is broadly in line with experience in past crisis cases. The contribution of net exports 
to growth is expected to diminish, and a revival of investment and ultimately consumption is projected to generate a slow recovery going forward. The recovery is forecast to pick up steam in 2011, with growth reaching 3 percent, boosted by planned investments in power-intensive sectors (which will temporarily reduce the current account surplus). Disinflation is forecast to continue, with the 12 month rate below 3 percent at year-end, reflecting subdued wages in the non-tradable sector and recent exchange rate appreciation. Medium-term current account surpluses are projected to improve slightly, driven mainly by a better outlook for the balance of services. Relative to post-crisis experience in other countries, Iceland's adjustment is likely to feature a longer period of elevated trade balances and suppressed consumption, given the initial level of debt overhang.

The forecast is subject to considerable uncertainty. Concerning growth, regulatory hurdles to further investments in energy intensive sectors, the pace of balance sheet repair, and global factors (which may affect external demand for Iceland's goods and/or Iceland's terms of trade), continue to generate significant downside risks. To add to this list, a resumption of the recent volcanic eruption-which would not be out of line with the past pattern for the volcano in question-could hit transport and tourism. In addition, the recent Supreme Court decision on foreign exchange indexed loans may delay private sector restructuring and discourage foreign investment (though over time it may deliver modest transfers to those benefiting from court decisions). Higher FDI could in contrast unlock higher growth.

Regarding inflation, supply-side influences could derail the projected disinflation path. Wage bargaining in Iceland is fairly centralized, and past post-recession patterns in Iceland point to the risk that wage increases in the tradable sector spread to the non-tradable sector, sparking cost-push pressures. The Stability Pact with labor and employer organizations has to date been a vehicle to manage such pressures, but has broken down. The authorities agreed that it would be important to revive it during the fall 2010 wage negotiation rounds.

Iceland's external and public debt remains sustainable, but their high levels amplify risks. Gross public debt is expected to decline to about 76 percent of GDP by 2015. Against a backdrop of deteriorating ratios in other advanced economies, this could place Iceland in a comparatively favorable position. However, the path could be derailed by too slow a pace of fiscal consolidation or the realization of large contingent liabilities. Iceland must also address a period of high debt rollover during 2011-12. Gross external debt is expected to fall to about 280 percent of GDP in 2010 and reach around 190 percent of GDP by 2015. Stress tests point to risks, mainly emanating from exchange rate depreciation. Although the gross level is still very high, it is not out of line with gross levels in other advanced globally integrated economies. Moreover, debts 
are very concentrated in multinational corporations with small footprints in Iceland, and these companies appear to have the foreign assets and foreign income necessary to service their debts.

Public and external assets are relatively high. Iceland's funded pension system is a net international creditor, and has been shifting assets into Iceland as opportunities arise. The public sector holds significant assets, including in the power sector, but also equity and collateral acquired during the crisis. Overall Iceland's net international investment position is negative by 30 percent of GDP at end-March 2010, while net public debt is projected to be 76 percent of GDP at end-2010. On both measures, Iceland is well within the range defined by its peers.

The Supreme Court ruling on foreign exchange indexed loans delivered a setback to the full restoration of financial stability. It is though not clear how broad an impact the judgment will have; for example, it is not clear how many types of exchange rate-linked loans are illegal. However, the Supreme Court judgments from this summer state that it is illegal to loan money in Icelandic krónur and link repayments of the loan to foreign currency exchange rates. On the other hand, the Court decided that loans that are specified in foreign currency and whose repayments are specified in foreign currency are legal. Such loans are subject to legal uncertainty, however, if the loan amount is disbursed in krónur and the repayments are also in krónur. Loan agreements containing clauses linking the loan to foreign currencies take many forms; as a result, there is enormous uncertainty about how many loans are illegal and how many are not. The Government has declared the willingness to treat all exchange-rate linked loans to household in the manner decided by the Supreme Court in September, and a bill of legislation to this effect has been proposed.

The private sector debt restructuring process could be slowed down by the Supreme Court ruling. While the ruling defacto restructures some foreign currency loans, it could take years for the legal process to determine which loans are subject to the ruling, with individuals foregoing the available restructuring mechanisms in the meantime. Moreover, the decision may encourage króna borrowers to delay their decision to restructure, in the hope that either they too benefit through future legal challenges to indexation clauses in their loans. Delays in debt restructuring would be costly from a macroeconomic perspective, given the potential boost to demand that balance sheet repair could deliver.

The authorities remain committed to a targeted, voluntary approach to restructuring. They acknowledged a need to speed up the process, but despite political pressures authorities reiterated that they will not undertake across-the-board debt write downs as it would do little to solve Iceland's overall debt overhang, and would merely shift problems from the private sector, including those able to pay, to the public sector. This would risk a public debt crisis, which could significantly raise interest rates for all Icelandic borrowers, and would ultimately have to be ad- 
dressed by additional fiscal adjustment measures affecting all Icelanders, including higher taxes and additional spending restraint. In contrast, the cost of a voluntary approach targeted to truly distressed borrowers can largely be borne by banks (which have adequate provisions), and can deliver deeper debt relief to those viable debtors requiring it.

The authorities reaffirmed their commitment to preserve exchange rate stability. This policy has contributed to the sharp decline of inflation and the shallower than-expected recession. The authorities and IMF staff agreed in the third Review that the exchange rate was undervalued from a medium-term perspective, but recognized a wide degree of uncertainty about the extent of undervaluation. Moreover, the more depreciated offshore rate sends an unmistakable signal that the currency would depreciate were it to be fully floated with no controls. Going forward, the authorities indicated that they would take advantage of recent króna strength. The Central Bank has started to purchase foreign exchange from the market—realizing \$14 million by the first week of September-and regular auctions are planned going forward. The accumulation of reserves would improve confidence and set the stage for the gradual elimination of capital controls in a stable exchange rate environment, and thus help to resolve short-term tensions. Reserve coverage indicators support this approach. While they have recently improved, they remain low, unless the impact of capital controls is accounted for.

Banking sector uncertainty stemming from the Supreme Court ruling has created an obstacle to the next capital control liberalization step. Capital controls continue to be an essential policy to stem large-scale capital outflows which could destabilize the currency. Nevertheless, as they hinder investment, and cannot be administered effectively for long periods of time, the program goal remains to remove them as quickly as feasible. The authorities have already taken a first step-liberalizing controls on new foreign exchange inflows - and some important preconditions to undertake the next step are now in place, including a better balance of payment outlook and an improving fiscal and public debt position. However, it was recognized that time would be needed to more fully secure financial system stability before proceeding. That is, banks should have enough liquidity to handle possible deposit outflows, and sufficient capital to buffer against potential losses. The recent Supreme Court decision on foreign exchange indexed loans had created considerable uncertainty along these dimensions. Once these uncertainties are sufficiently resolved, a next step can be taken, and consistent with the August 2009 strategy, this will involve release of controls on the sale and conversion of longer term assets.

Iceland's banking and currency crisis is virtually unprecedented. Although the burden of the old banks failure will be borne in large part by foreign creditors, the old banks collapse also made a profound impact on domestic private sector balance sheets, increased the magnitude of the 
economic adjustment, and delayed recovery beyond what other countries have generally experience. According to the latest forecast from the Central Bank of Iceland, which was published in November, it appears that GDP in Iceland bottomed out in the second quarter 2010 and is now approximately 9 percent lower than it was just before the onset of the crisis. Thus the contraction lasted more than two years. According to the forecast, the outlook is for output to reach its pre-crisis level by year-end 2014. Clearly, though there is also a permanent loss in potential output, currently estimated at approximately 5 percent. On the whole the contraction in Iceland was notably deeper than in most developed countries, yet it was not deeper than in countries hardest hit by the crisis. Nonetheless recovery has come later in Iceland than it has elsewhere.

\subsection{Fiscal Policy}

The authorities and IMF staff agreed on some minor modifications to fiscal adjustment targets in the third Review in September. The 2011 general government primary surplus target was reduced from $1 \frac{11}{4}$ to $1 / 2$ percent of GDP, while the medium-term target was reduced from $63 / 4$ to 6 percent of GDP. The combination of growing risks to the economic outlook and ample financing motivated the change for 2011, while strong projected debt dynamics underlie the medium-term modification. The revised consolidation path remains in line the ambitious consolidation programs in the Nordic countries. There was discussion about a further reduction of the medium-term target, but it was agreed that the uncertainty regarding contingent banking sector liabilities called for caution. Targets will be kept under review. Iceland's strong projected debt dynamics suggest more room to moderate the pace of adjustment if the government continues to avoid absorbing the private sector's crisis-related losses, and if contingent financial sector liabilities prove to be contained.

The authorities are broadly on track to achieve the 2010 fiscal target. The apparent softening of activity during the second quarter had a temporary impact on consumption tax revenue collections, but the overall revenue target remains within reach due to over performance of property and income taxes. Given under spending in some areas (totaling about $1 / 2$ percent of GDP) and over performance by local governments (about $1 / 4$ percent of GDP to date) the 2010 general government primary deficit target remains well within reach.

Sufficient measures have been identified to deliver the 2011 fiscal target. The general government primary balance target of $1 / 2$ percent of GDP will be achieved by a central government primary balance of $1 / 2$ percent of GDP, along with a balanced local government position. The projected local government outcome will be supported by the introduction of a stronger framework, while the central government target will be met 
through $3^{1 / 2}$ percent of GDP in measures. The authorities explained that they will emphasize spending cuts, to keep the broad balance envisioned in the consolidation plan originally agreed with social partners.

Revenue measures will amount to about 0.6 percent of GDP. The authorities intend to increase the capital and corporate income tax rates from 18 to 20 percent. These measures will move Iceland closer to the tax rate prevailing in other Nordic countries. Expenditure measures will on the other hand amount to about 3 percent of GDP. The authorities have approved lower spending ceilings by ministry, with underlying gains to be delivered primarily by administrative reorganization (including employment rationalization); wage restraint, and benefit restraint. The measures are expected to reduce general government employment by 7.6 percent and employee compensation by 13 percent relative to 2008, keeping them in line with historical values relative to the private sector.

The near-term financing outlook is benign and discussions focused on how to orchestrate Iceland's return to international markets. The authorities have now financed about 80 percent of their 2010 need via domestic markets, and maintain some 14 percent of GDP in deposits in the CBI (enough to handle gross financing needs for the next 27 months). However, still muted global risk appetite, the uncertainty about banking sector contingent liabilities, and lingering uncertainty concerning the Icesave dispute create a barrier to an immediate return to international markets. To continue to lay the groundwork for a return to markets at a better conjuncture, the authorities are working to update their medium-term debt management strategy to fully capture the impact of recent debt buyback operations. Concerning domestic debt, it was agreed that a key priority would be to reduce the level of non-market debt, including by repurchase (using excess government deposit balances) and via exchange.

Completion of Iceland's medium term fiscal adjustment will require the identification and implementation of additional fiscal measures. To achieve the fiscal target in the plan (a general government primary balance of 6 percent of GDP by 2013) 3 percent of GDP in additional measures will need to be defined for 2012-13. There is a broad consensus in Iceland that the measures should be balanced between revenue increases and expenditure cutbacks. There is much less consensus about what underlying measures to take, although IMF technical assistance has helped to lay out revenue options. The authorities and IMF staff agreed in the third Review that different mixes would likely have different macroeconomic implications, with some Iceland-specific nuances: excessive reliance on capital and corporate income taxes may constrain investment, but sharp movements in consumption taxes would temporarily elevate inflation (and affect the large stock of CPI indexed debt). Excessive reliance on public investment cutbacks would affect the stock of public capital, putting another unwelcome barrier in front of private sector investment and sustained long term growth. A focus on wage and transfer restraint 
could have salutary effects on the labor market, contributing to restrained unit labor costs and higher employment levels, although this would depend on continued cooperation with representatives of labor unions.

The Nordic countries stand out in a comparison of the countries that have adopted the most extensive consolidation measures as defined by the IMF. The austerity measures currently being implemented in Iceland are similar in scope to those in the Nordic countries during the 1980s and 1990s. The estimated improvement in Iceland's primary balanced between 2009 and 2013 amounts to 13 percent of GDP, 12 percent for the Treasury and 1 percent for local governments. The largest improvement in the primary balanced occurred in Finland, over a nine-year period from 1992-2000. The improvement was similar to that in Denmark in the early 1980s and in Sweden in the early 1990s, but takes place over a shorter period. In the 1980s and 1990s, Ireland and the UK undertook consolidation measures that generated an improvement amounting to 8.5 percent of GDP over a six-year period. Now the British are faced with having to adopt similar measures, and they intend to achieve an improvement of almost 10 percent of GDP in six years. Similarly, Latvia which was hit especially hard by the financial crisis, intends to improve its fiscal performance by 7.5 percent of GDP in the next four years. The Irish have not announced a fully fledged plan in the wake of recent development concerning the recapitalization of their banking system, but discussions indicate that the improvement in the primary balance must lie in the range 13-15 percent of GDP. 